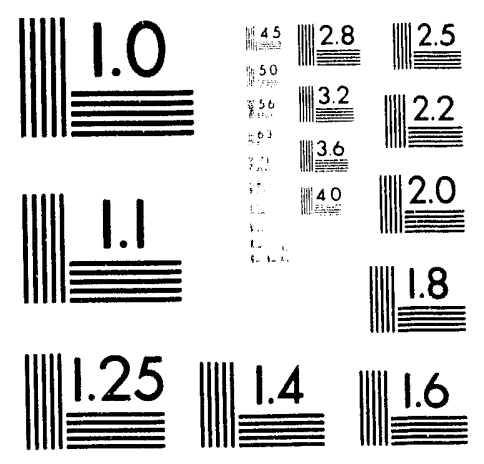



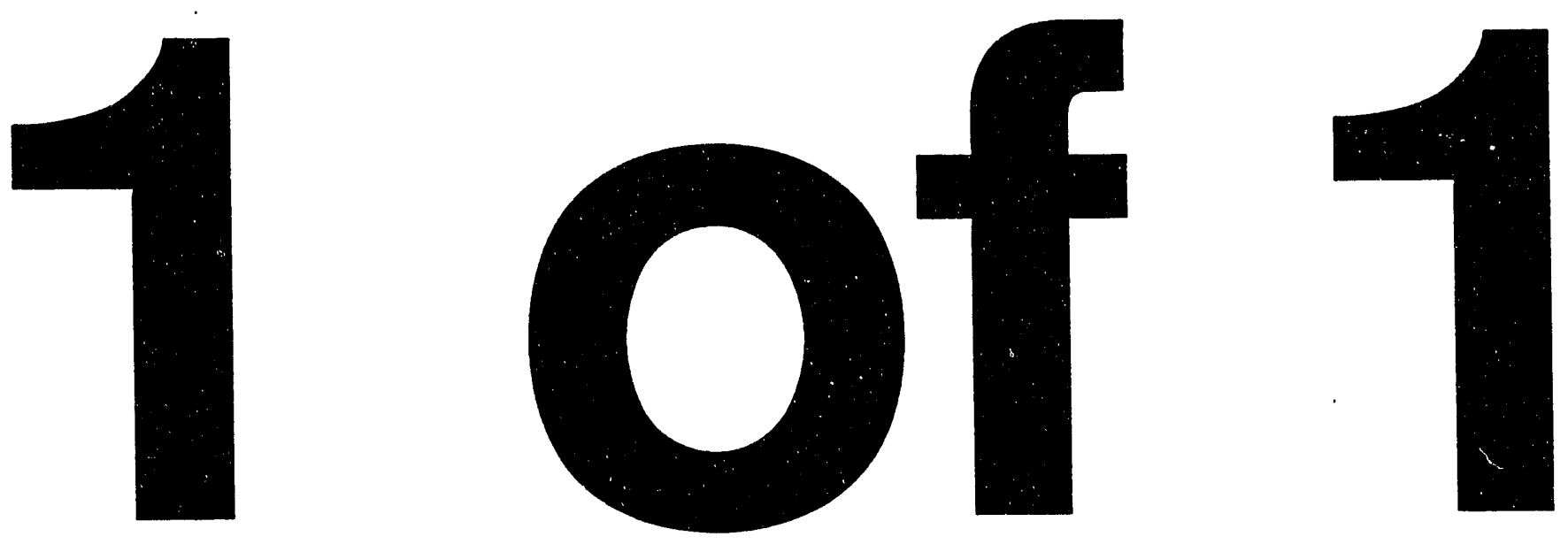
ARGONNE NATIONAL LABORATORY

9700 South Cass Avenue, Argonne, Illinois 60439

\title{
Preliminary Assessment Report for Bee Caves Armory \\ (Former Nike BG-80 Fire Control Facility), Installation 48055, Austin, Texas
}

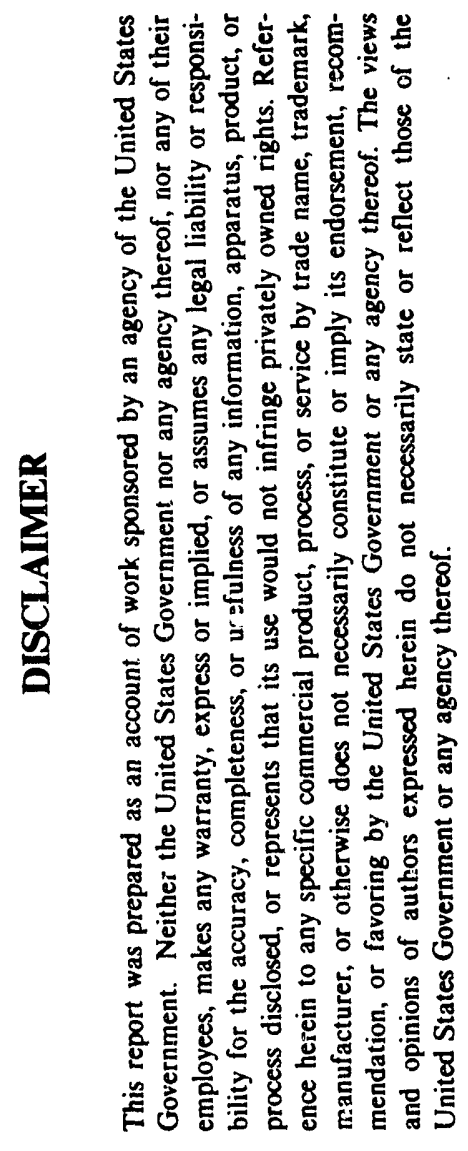

\author{
Prepared for \\ National Guard Bureau, Army Directorate \\ Aberdeen, Maryland
}

August 1993

Prepared by

Applied Geosciences and Environmental Management Section

Environmental Research Division

Argonne National Laboratory 


\begin{tabular}{|c|c|c|c|}
\hline \multicolumn{2}{|c|}{ REPORT DOCUMENTATION PAGE } & \multicolumn{2}{|c|}{$\begin{array}{l}\text { FORM APPROVED } \\
\text { OMB No. 0704-(0188 }\end{array}$} \\
\hline \multicolumn{4}{|c|}{$\begin{array}{l}\text { Public reporting burden for this collection of information is estimated to average } 1 \text { hour per response. including } \\
\text { the time for reviewing instructions, searching existing data sources, gathering and maintaining the data needed. } \\
\text { and completing and reviewing the collection of information. Send comments regarding this burden estimate or } \\
\text { any other aspect of this collection of information, including suggestions for reducing this burden to Washington } \\
\text { Headquarters Services. Directorate for Information Operations and Reports, } 1215 \text { Jefferson Davis Highway, } \\
\text { Suite } 1204 \text {. Arlington. VA } 22202-4302 \text { and to the Office of Management and Budget, Paperwork Reduction } \\
\text { Project (07()4-(1)1880), Washingt(on. DC 205(3). }\end{array}$} \\
\hline $\begin{array}{l}\text { 1. AGENCY USE ONLY } \\
\text { (Leave Blank) }\end{array}$ & $\begin{array}{l}\text { 2. REPORT DATE } \\
\text { August } 1993\end{array}$ & $\begin{array}{l}\text { 3. REPORT TYPE AND I } \\
\text { Preliminary site visit to }\end{array}$ & $\begin{array}{l}\text { ATES COVERED } \\
\text { complete assessment. }\end{array}$ \\
\hline \multicolumn{3}{|c|}{$\begin{array}{l}\text { 4. TITLE AND SLBTITLE Preliminary Assessment Report for Bee Caves } \\
\text { Armory (former Nike BG-80) Fire Control Facility). Installation } 48(1) 55 \text {, } \\
\text { Austin. Texas }\end{array}$} & $\begin{array}{l}\text { 5. FUNDING NUMBERS } \\
\text { MIPR-378\% }\end{array}$ \\
\hline \multicolumn{3}{|c|}{$\begin{array}{l}\text { 6. ALTHOR(S) } \\
\text { Clyde Dennis }\end{array}$} & MIPR-4I88 \\
\hline \multicolumn{3}{|c|}{$\begin{array}{l}\text { 7. PERFORMING ORGANIZATION NAME(S) AND ADDRESS(ES) } \\
\text { Candace M. Rose } \\
\text { Argonne National Laboratory } \\
9700 \text { South Cass Avenue } \\
\text { Argonne. IL } 60439\end{array}$} & $\begin{array}{l}\text { 8. PERFORMING } \\
\text { ORGANIZATION } \\
\text { REPORT NUMBER } \\
\text { None }\end{array}$ \\
\hline \multicolumn{3}{|c|}{ 9. SPONSORING/MONITORING AGENCY NAME(S) AND ADDRESS(ES) } & $\begin{array}{l}\text { 10. SPONSORING/ } \\
\text { MONITORING AGENCY } \\
\text { REPORT NUMBER } \\
\text { IR-CR-93()7X }\end{array}$ \\
\hline \multicolumn{4}{|c|}{ 11. SUPPLEMENTARY NOTES } \\
\hline \multicolumn{3}{|c|}{$\begin{array}{l}\text { 12a. DISTRIBUTION/AVAILABILITY } \\
\text { Distribution is to government agencies only. } \\
\text { Outside requests must be made to the Army National Guard Bureau. }\end{array}$} & $\begin{array}{l}\text { 12b. DISTRIBUTION } \\
\text { CODE }\end{array}$ \\
\hline \multicolumn{4}{|c|}{ 13. ABSTRACT (MAXIMUM 200 WORDS) } \\
\hline \multicolumn{4}{|c|}{ This report addresses the information necessiary to complete the PA. } \\
\hline \multicolumn{3}{|l|}{ 14. SUBJECT TERMS } & $\begin{array}{l}\text { 15. NUMBER OF PAGES } \\
\text { PA-76 } \\
\text { 16. PRICE CODE }\end{array}$ \\
\hline $\begin{array}{l}\text { 17. SECURITY } \\
\text { CLASSIFICATION OF } \\
\text { REPORT }\end{array}$ & $\begin{array}{l}\text { 18. SECURITY } \\
\text { CLASSIFICATION OF } \\
\text { THIS REPORT }\end{array}$ & $\begin{array}{l}\text { 19. SECURITY } \\
\text { CLASSIFICATION OF } \\
\text { ABSTRACT }\end{array}$ & $\begin{array}{l}\text { 20. LIMITATION OF } \\
\text { ABS TRACT }\end{array}$ \\
\hline Unclassified & Unclassified & Unclassified & Unlimited \\
\hline
\end{tabular}


PA for Bee Caves Armory 


\section{Contents}

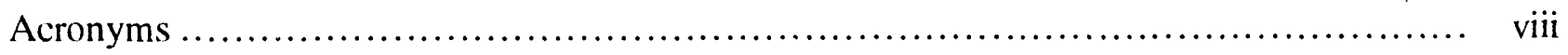

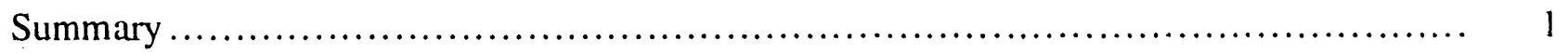

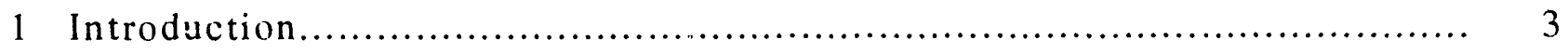

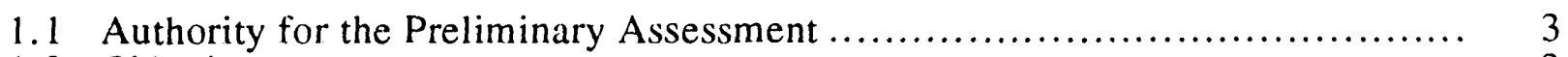

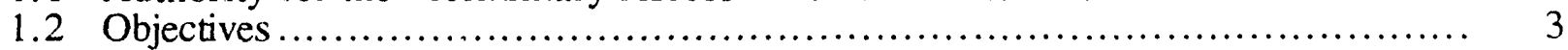

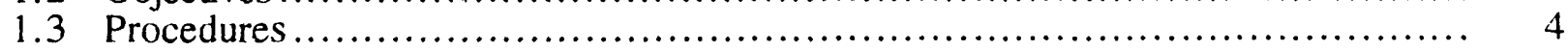

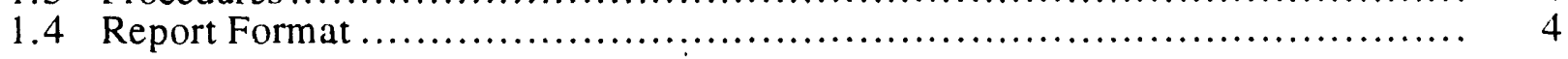

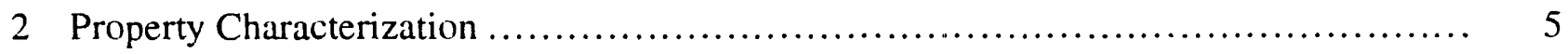

2.1 General Property Information.............................................. 5

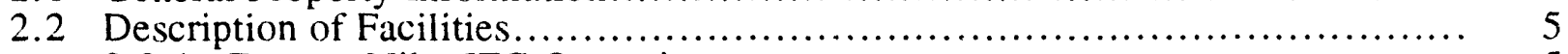

2.2.1 Former Nike IFC Operations............................................ 5

2.2.2 Armory and Training Site............................................... 9

2.2.3 Former Vehicle Wash Area ............................................ 12

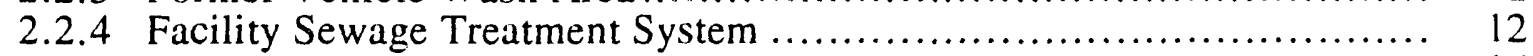

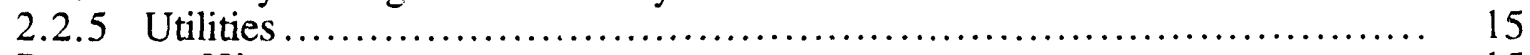

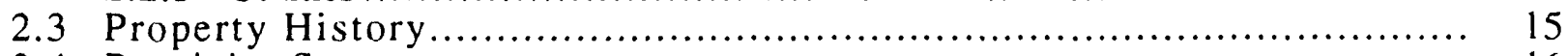

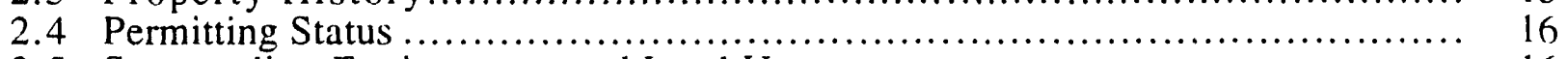

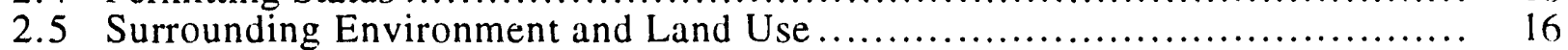

2.5.1 Demographics and Land Use........................................ 16

2.5.2 Climate ............................................................. 18

2.5.3 Physiography, Soils, and Surface Hydrology........................... 19

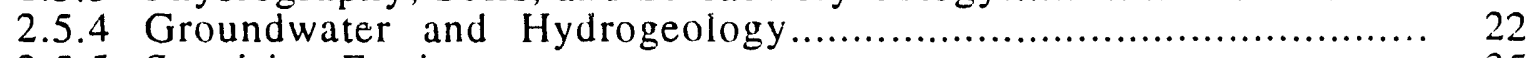

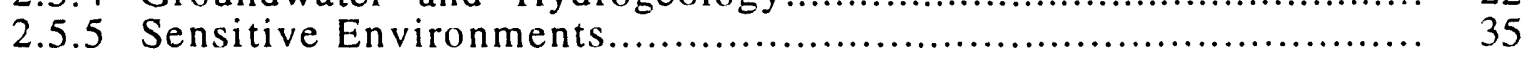

3 Environmentally Significant Operations ..................................... 40)

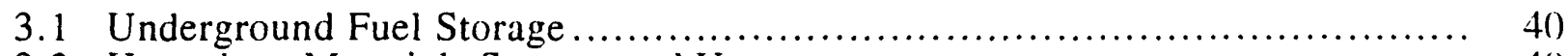

3.2 Hazardous Materials Storage and Use..................................... 40

3.2.1 Use of Hazardous Materials in ARNG Operations ...................... 42

3.2.2 Use of Hazardous Materials in Nike IFC Operations................... 42

3.2.3 Hazardous Construction Materials....................................... 44

3.3 Disposal of Hazardous Waste in Dry Wells ................................... 45

3.4 Release of Untreated or Hazardous Waste Water........................... 45

4 Known and Suspected Releases ........................................ 47

4.1 Releases to Groundwater .............................................. 47

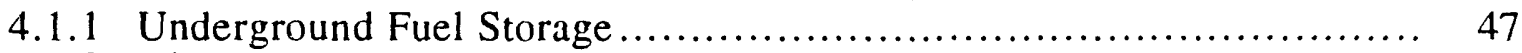

4.1.2 Disposal of Hazardous Waste in Dry Wells ........................... 47

4.1.3 Release of Untreated Waste Water ................................... 48

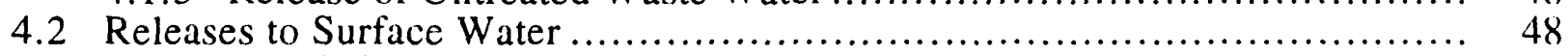

4.3 Releases to Soil .......................................................... 49

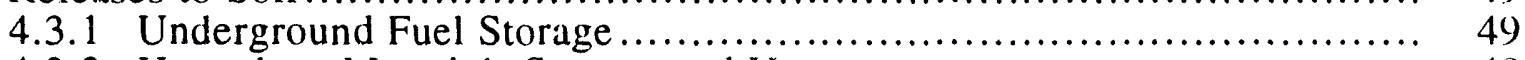

4.3.2 Hazardous Materials Storage and Use................................... 49

4.3.3 Release of Untreated Waste Water ..................................... 50

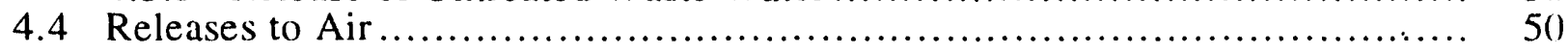




\section{Contents (Cont.)}

4.5 Other Releases ........................................................ 51

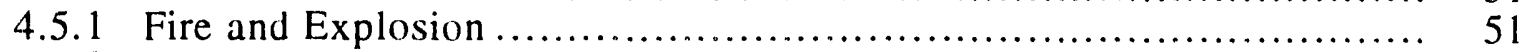

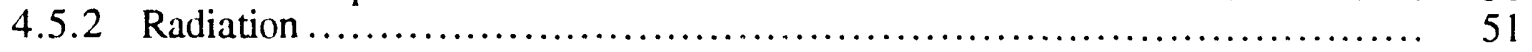

5 Human and Environmental Receptors........................................ 54

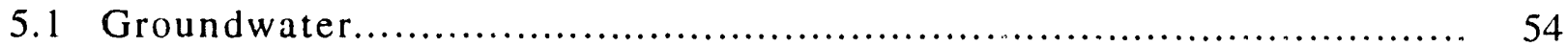

5.2 Surface Water............................................................... 54

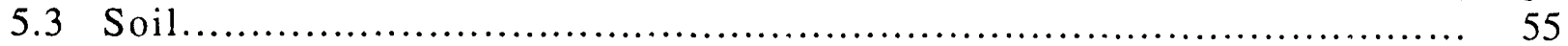

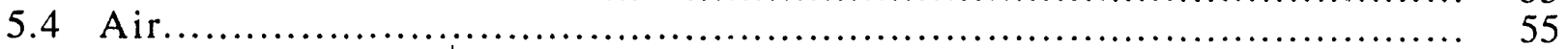

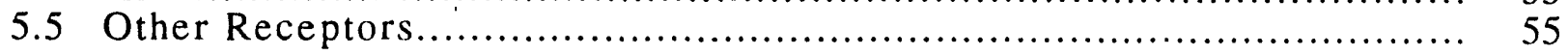

6 Preliminary Assessment Findings and Conclusions............................ 56

6.1 Summary of Preliminary Assessment Findings .......................... 56

6.1 .1 Underground Fuel Storage ......................................... 56

6.1.2 Hazardous Materials Storage and Use............................. 57

6.1.3 Disposal of Hazardous Waste into Two Dry Wells.................... 57

6.1.4 Release of Untreated or Hazardous Waste Water from the Facility Water Treatment System .......................................... 58

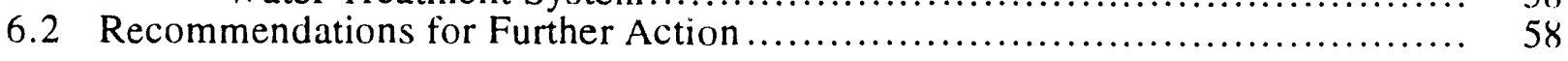

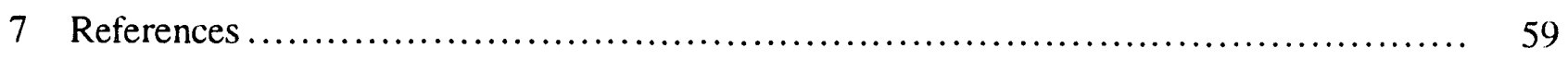

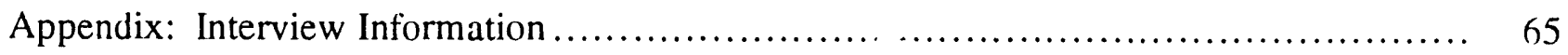

\section{Figures}

1 General Location of Bee Caves Armory......................................... 6

2 Layout of Bee Caves Armory Property........................................ 8

3 Bee Caves Armory Site Plan ........................................... 10

4 Location of the Facility Waste Water Treatment System ....................... 13

5 Design of the Facility Waste Water Treatment System .......................... 14

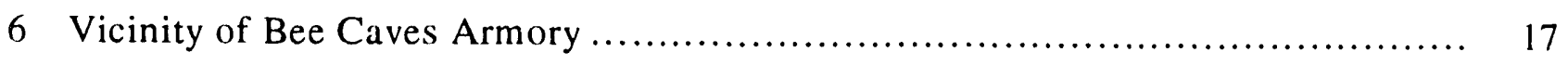

7 Major Physiographic Provinces of Texas....................................... 20

8 Location of Regional Surface Waters............................................ 23

9 Geologic Section across Travis County, Texas ............................... 25

10 Hydrogeologic Framework of Travis County, Texas .............................. 29 


\section{Figures (Cont.)}

11 Location of Water Wells within a Four-Mile Radius of the Bee Caves Armory

12 Locations of Environmentally Significant Operations at Nike BG-80

Fire Control Facility

\section{Tables}

1 Identifying Information for Bee Caves Armory

2 Driller's Log of Well YD-58-42-401, near the Bee Caves ARNG Property

3 Water Wells in the Vicinity of the Bee Caves Armory............................ 33

4 Rare or Endangered Plants in the Vicinity of the Bee Caves ARNG Property

5 Rare or Endangered Animals in the Vicinity of the Bee Caves ARNG Property ................................................................. 38

6 Bee Caves Armory Hazardous Chemical Inventory .............................. 43

7 Nike Integrated Fire Control Facility Hazardous Chemical Inventory ................ 44

8 Summary of Samples of Building Construction Materials Collected Containing Asbestos. 


\section{Acronyms}

$\begin{array}{ll}\text { ACM } & \text { asbestos-containing material } \\ \text { ARNG } & \text { Army National Guard } \\ \text { ATCHD } & \text { Austin-Travis County Health Department } \\ \text { CERCLA } & \text { Comprehensive Environmental Response, Compensation, and Liability Act } \\ \text { COE } & \text { U.S. Army Corps of Engineers } \\ \text { DHUD } & \text { U.S. Department of Housing and Urban Development } \\ \text { ECAS } & \text { Environmental Compliance Assessment System } \\ \text { EPA } & \text { U.S. Environmental Protection Agency } \\ \text { ESE } & \text { Environmental Science and Engineering, Inc. } \\ \text { ESO } & \text { environmentally significant operation } \\ \text { FISP } & \text { Facility Inventory and Stationing Plan } \\ \text { FWS } & \text { U.S. Fish and Wildlife Service } \\ \text { GFC } & \text { Generator and Frequency Changer } \\ \text { HIPAR } & \text { High-Power Acquisition Radar } \\ \text { IC } & \text { Interconnecting Corridor } \\ \text { IFC } & \text { Integrated Fire Control } \\ \text { IRP } & \text { Installation Restoration Program } \\ \text { LPD } & \text { low-pressure dosed } \\ \text { LPG } & \text { liquid propane gas } \\ \text { MLA } & \text { Missile Launch Area } \\ \text { NGB } & \text { National Guard Bureau } \\ \text { NOAA } & \text { National Oceanic and Atmospheric Administration } \\ \text { PA } & \text { preliminary assessment } \\ \text { PCB } & \text { polychlorinated biphenyl } \\ \text { POL } & \text { petroleum, oils, and lubricants } \\ \text { TPWD } & \text { State of Texas Parks and Wildlife Department } \\ \text { TWC } & \text { Texas Water Commission } \\ \text { TWDB } & \text { Texas Water Development Board } \\ \text { USAEC } & \text { U.S. Army Environmental Center (formerly USATHAMA) } \\ \text { USATHAMA } & \text { U.S. Army Toxic and Hazardous Material: Agency (now USAEC) } \\ \text { USGS } & \text { U.S. Geological Survey } \\ \text { UST } & \text { underground storage tanks } \\ \text { USTP } & \text { Underground Storage Tank Program } \\ & \end{array}$




\section{Preliminary Assessment Report for \\ Bee Caves Armory \\ (Former Nike BG-80 Fire Control Facility), \\ Installation 48055, \\ Austin, Texas}

\section{Summary}

This report presents the results of the preliminary assessment (PA) conducted by Argonne National Laboratory at the Texas Army National Guard (ARNG) property in Austin, Texas. Preliminary assessments of federal facilities are being conducted to compile the information necessary for completing preremedial activities and to provide a basis for establishing corrective actions in response to releases of hazardous substances. The principal objective of the PA is to characterize the site accurately and determine the need for further action by examining site activities, quantities of hazardous substances present, and potential pathways by which contamination could affect public health and the environment. This PA satisfies, for the Bee Caves Armory property, the requirements of the Department of Defense Installation Restoration Program.

The Bee Caves Armory is a 12.55-acre site located in Travis County in the central portion of Texas just west of the city limits of Austin, the county seat and state capital. On the basis of the review of both historical and current activities, the Bee Caves property poses minimal risk to human health and the environment. Formerly a Nike-Hercules Missile Program Integrated Fire Control Area, the facility is now occupied by the 111th Area Support Group and the 1104th Transportation Detachment. The two units, with authorized strength totaling 139, assemble for training one weekend per month. Training of signal battalion personnel neither involves the use of hazardous materials of any consequence nor results in the generation of hazardous wastes. Vehicies assigned to the units are serviced and maintained at nearby Camp Swift. The ARNG activities performed at the facility, including the storage and use of limited quantities of hazardous or flammable fluids required for grounds- and housekeeping activities, do not result in the release of significant amounts of hazardous waste.

Of concern is the potential for hazardous waste to be present on the property as a result of the former Nike Missile Base operations or in the form of original construction materials. Environmentally sensitive operations associated with the property from that period include (1) underground fuel storage, (2) hazardous materials storage/use, (3) disposal of hazardous 
waste into two dry wells, and (4) release of untreated or hazardous waste water from the former facility water treatment system. Actions have been taken to mitigate these potential problems:

1. The abandoned 6,00()-gal underground diesel fuel storage tank has been removed. Inspection of the underground storage tank and excavated soil/rock indicated that release of significant quantities of hazardous chemicals did not occur.

2. Aside from diesel fuel used to power the on-site electrical generator, leadcontaining paints represented the largest quantity of hazardous material used as part of the former Nike operations. Lesser quantities of lubricating oils, solvents, and herbicides were also present. The volume of hazardous materials required on-site as part of Nike missile fire control activities was low, and most of these materials were consumed. A survey performed in early 1993 under the direction of the U.S. Army Corps of Engineers confirmed that asbestos is present on-site in the form of building construction and insulation materials.

3. No records are available regarding disposal of Nike operations waste fluid. . Whether two dry wells that, according to the 1959 site plan of the former Nike site, were located in the northwestern portion of the property were used for disposal of waste fluids is unknown. The presence of the dry wells could not be confirmed during the site survey. If the dry wells were present as indicated in the site plan and then were filled at the time of deactivation of the former Nike site, use of the dry wells for disposal of the limited quantities of hazardous waste fluids generated as part of the former Nike operations is unlikely to have resulted in the release of hazardous constituents sufficient to pose a significant threat to the environment or to the surrounding population.

4. Finally, the former, aging sewage treatment facility has been replaced by an upgraded treatment facility approved by the local health authorities.

Because of the actions taken to mitigate potential contamination at the site, no further preliminary assessment/Installation Restoration Program action is recommended for this property. To protect workers on the site, abatement of asbestos-containing materials, as outlined in the February 1993 asbestos survey, is recommended. 


\section{Introduction}

This document is a report of the preliminary assessment (PA) conducted by Argonne National Laboratory at the Texas Army National Guard (ARNG) property known as Bee Caves Armory, located in Austin, Texas. The facility is a former Nike-Hercules Missile Defense Program Integrated Fire Control Area.

\subsection{Authority for the Preliminary Assessment}

The National Guard Bureau, Army Directorate, has engaged Argonne to perform PAs of selected ARNG properties. These assessments are being done in a manner consistent with both the Department of Defense Installation Restoration Program (IRP) and the U.S. Environmental Protection Agency's (EPA's) Potential Hazardous Waste Site Preliminary Assessment Guidance. Preliminan y assessments of ARNG properties are conducted under the authority and direction of the IRP; the Comprehensive Environmental Response, Compensation, and Liability Act (CERCLA or, more commonly, Superfund); and the Superfund Amendments and Reauthorization Act of 1986 (Public Law 99-499).

\subsection{Objectives}

This PA report is based on existing information from the ARNG records that were made available to Argonne investigators and from other sources. Although this PA effort did not extend to the generation of new data, it nonetheless identifies areas where existing data are incomplete, unreliable, or ambiguous and recommends ways to address such shortcomings.

The objectives of the PA are to satisfy the requirements of the IRP and to

- Identify and characterize the environmentaily significant operations (ESOs),

- Identify property areas or ESOs that may require a site investigation,

- Identify ESOs or areas of environmental contamination that may require immediate removal, 
- Identify properties for which no further action is needed, and

- Provide information sufficient to prescore the site with the EPA's PA Score Sheets (September 1991).

\subsection{Procedures}

The PA began with a review of ARNG files located at Texas ARNG Headquarters at Camp Mabry in Austin, Texas, on May 24, 1993. Other relevant information was obtained on May 25 from the Texas Water Commission, the Soil Conservation Service, and other state and federal agencies. A site visit was conducted on May 26, to obtain additional information through direct observation and interviews with personnel familiar with the property and its operations (Dennis 1993).

\subsection{Report Format}

This PA report presents a summary and evaluation of the data relevant to the PA for this property. Section 2 describes the property and its surrounding environment and land uses. Section 3 identifies and characterizes the ESOs at the site. Section 4 discusses known and suspected releases to the environment, and Section 5 discusses potential human and environmental receptors for such releases. Section 6 summarizes the findings and conclusions, discusses the quality and reliability of the supporting information, identifies areas requiring further action, and (as appropriate) suggests how such actions can be accomplished. Section 7 lists pertinent materials reviewed. The Appendix gives interview information. 


\section{Property Characterization}

\subsection{General Property Information}

The Bee Caves Armory is located in Travis County in central Texas, just west of the city of Austin, the county seat and state capital. Total land within post boundaries comprises 12.55 acres. The property. which is partitioned in four parcels, is situated on a hill at the intersection of Bee Caves Road (State Road 2244) and St. Stephens Road (GSA 1988). The 8.71-acre armory and training area is located on the crest of the hill. A second 0.72 -acre parcel located partially down the hill contains the entrance tc the site along with the former facility sewage treatment plant. A third 0.93 -acre parcel at the base of the hill is the reception point for utility services. Roadway easements connecting the three parcels of land make up the remaining 2.19 acres. The area surrounding the AF.NG property has been developed as a high-value, urban residential area. Commercial development along Bee Caves Road is limited. Figure 1 shows the general location of the Bet Caves ARNG property, and Table 1 lists pertinent information about it. Figure 2 provides a layout of the Bee Caves ARNG property.

\subsection{Description of Facilities}

The Bee Caves ARNG pioperty is licensed to the Texas National Guard as an armory and division data center. The facility is occupied by the 111th Area Support Group and the 1104th Transportation Detachment. The two units, with authorized strength of 135 and 4, respectively. assemble for basically classroom-type training one weekend per month. Regular full-time personnel number 17 (GSA 1988). The property was originally developed in approximately 1960 as a U.S. Nike-Hercules Missile Defense Program Integrated Fire Control (IFC) Area. Some site facilities were removed when Nike operations were terminated. Others have since been abandoned. The ARNG uses some facilities for purposes other than their original designations. Use of other facilities remains unchanged.

\subsubsection{Former Nike IFC Operations}

General information on the Nike Missile program has been compiled by both the Army Corps of Engineers (ESF. 1984) and the U.S. Army Toxic and Hazardous Materials Agency 

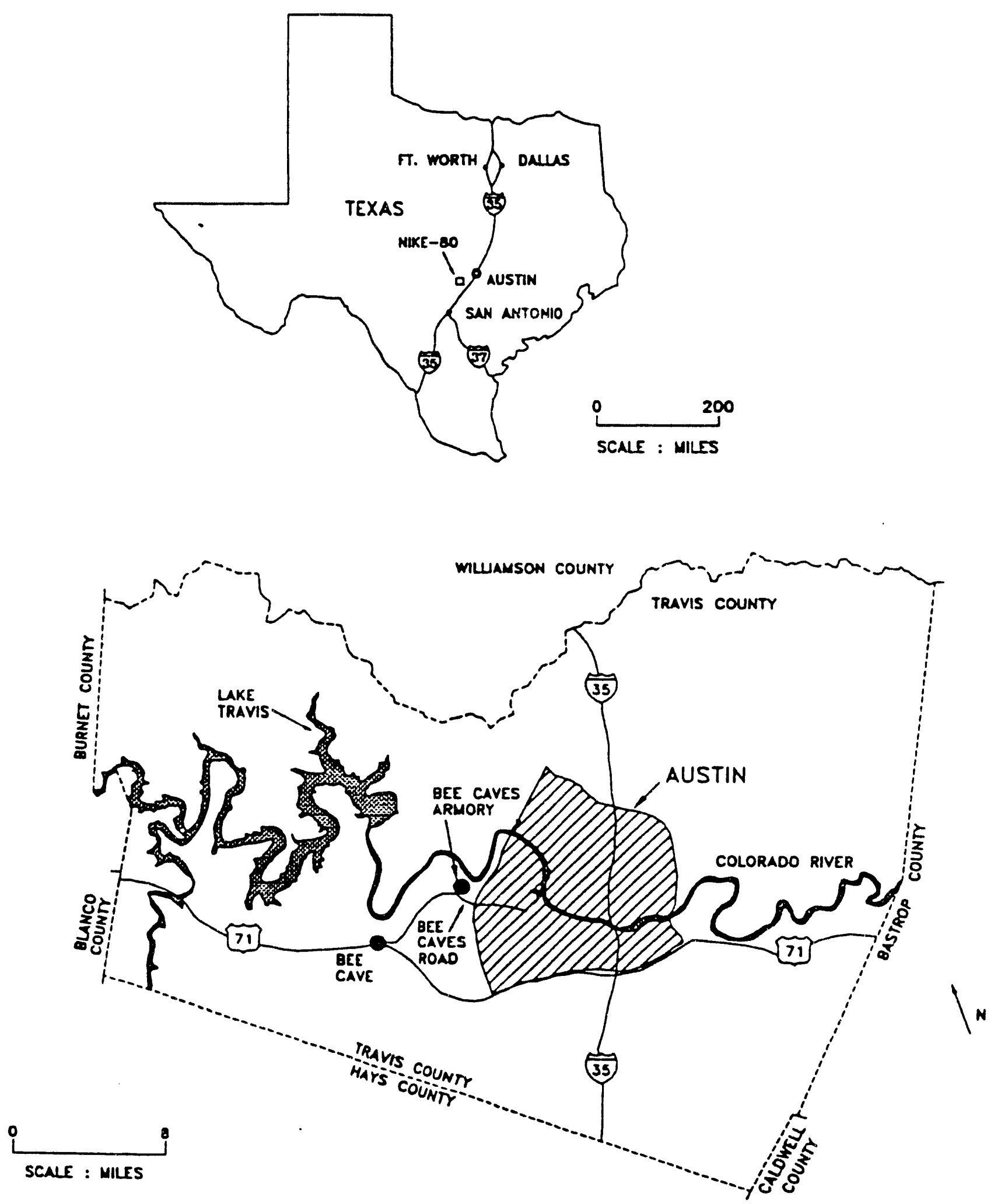

FIGURE 1 General Location of Bee Caves Armory (Sources: USGS 1988a, USGS 1988b) 
TABLE 1 Identifying Information for Bee Caves Armory

\begin{tabular}{ll}
\hline Installation address & $\begin{array}{l}\text { Bee Caves Armory } \\
408 \text { St. Stephens Road } \\
\text { Austin, Texas 78746 }\end{array}$ \\
$\begin{array}{l}\text { Geographic location } \\
\text { Latitude } \\
\text { Longitude }\end{array}$ & $\begin{array}{l}30^{\circ} 16^{\prime} \mathrm{N} \\
97^{\circ} 43^{\prime} \mathrm{W}\end{array}$ \\
FISPa installation number & 48055 \\
Commander & LTC Raymond C. Peters \\
Types of facilities & Armory \\
License information & Federally owned, licensed to the state of Texas \\
Principal contact & $\begin{array}{l}\text { Paul Powell } \\
(512) \quad 465-5629\end{array}$ \\
\hline
\end{tabular}

a Facility Inventory and Stationing Plan.

(USATHAMA) (LETC 1986). Although some information about the Nike defense program is available, much remains classified for reasons of national security. Nevertheless, taken together, these two reports represent the most complete assemblage of information on the Nike Missile program from an environmental perspective.

A typical Nike battery consisted of two distinct and separate operating units, the Launcher area and the IFC area (ESE 1984). The Launcher area was usually 40-50 acres in size, and the IFC was typically 10-50 acres. Because of instrumentation requirements, the two areas were separated by a minimum distance of $0.56 \mathrm{mi}$ to a distance of $2.98 \mathrm{mi}$, with a line of sight between them for communication and tracking purposes. When topography permitted, as was the case for the former Bee Caves Nike facility, the IFC was placed at the higher elevation. Barracks facilities were either included as a third battery area or, as for the Bee Caves facility, were incorporated into the IFC area. 


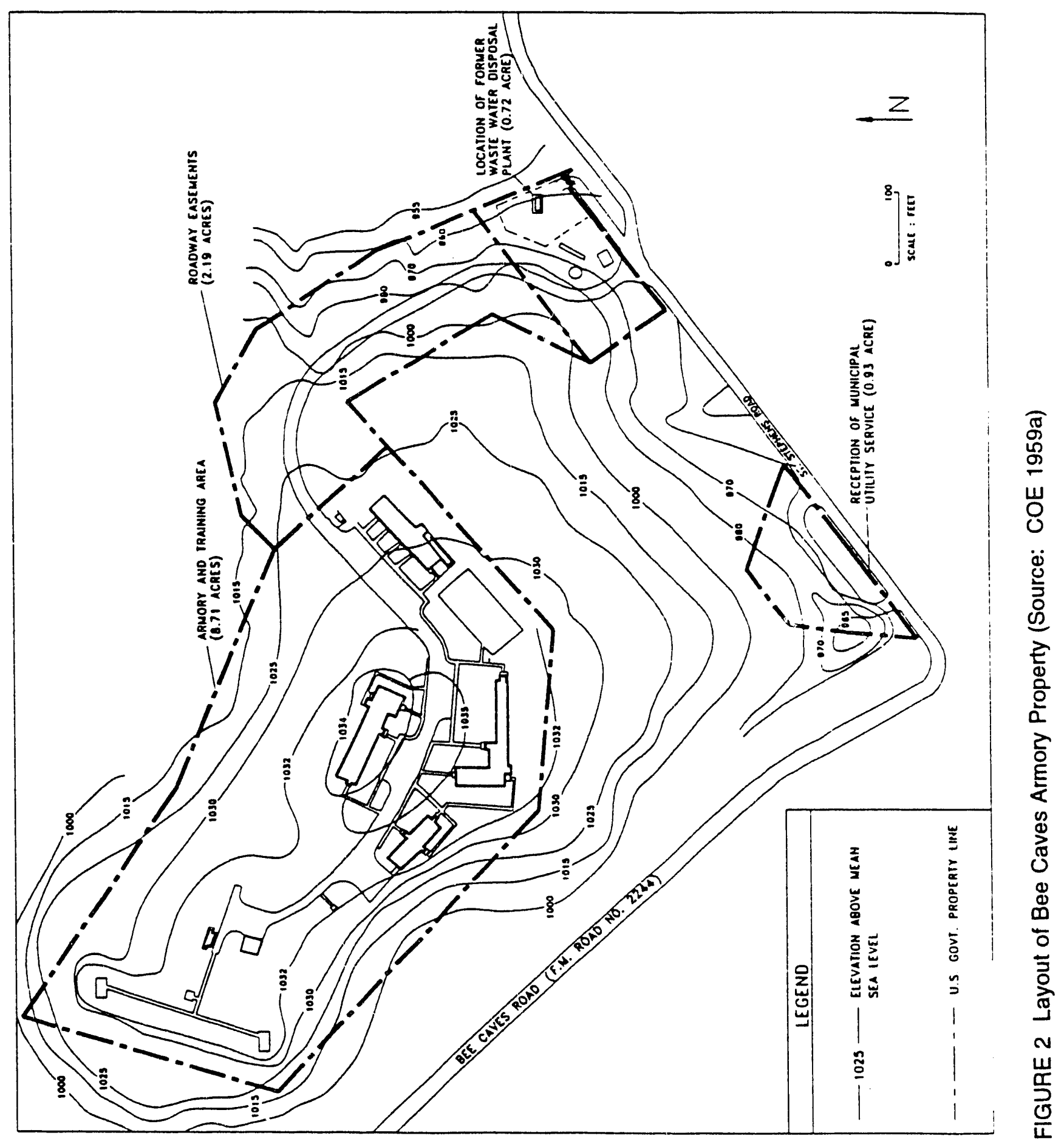


Of the two operating areas making up a missile battery, the control area clearly has a lower potential for environmental contamination. Potential areas of contamination at a typical IFC area include:

- Motor pool maintenance area, if present;

- Diesel fuel, fuel oil, and/or gasoline storage systems;

- On-site landfill or unofficial, conveniently located disposal areas; and

- Facility waste water treatment system.

Documentation regarding deactivation of the Bee Caves IFC area was unavailable for this PA, although a June 1959 site plan of the former Nike installation was available (COE 1959b). The plan of the former installation and the site survey that was performed indicate that motor pool facilities, including vehicle maintenance operations and gasoline storage, were not a part of the Nike IFC operations. When the Nike facility was deactivated before transfer of the property to the ARNG, the power generating equipment and radar and communication equipment associated with Nike operations were removed. A 6,000-gal underground storage tank (UST) containing diesel fuel for operation of the power generating equipment was drained at the time of Nike deactivation but not removed. As discussed in Section 4.1.1, the tank has since been removed. No evidence of an on-site landfill or other waste disposal area was seen during the site survey, although the site plan for the former Nike facility identifies the locations of two dry wells. The Nike facility waste water treatment system remained in operation after transfer of the property to the ARNG; it was replaced in 1991. The two dry wells and the former facility waste water treatment system are discussed further in Sections 3.3 and 3.4, respectively.

\subsubsection{Armory and Training Site}

The 8.71-acre armory, as depicted in Figure 3, contains eight buildings totaling approximately $23,000 \mathrm{ft}^{2}$ of floor space (TXARNG 1980). The buildings, constructed in approximately 1960 for the former Nike Missile Fire Control Area operations, are set on concrete slab foundations with cinder block walls and generally have flat tar-and-gravel roofs. The four main buildings are used by the ARNG for administrative, dining, assembly, and classroom training activities. Four smaller structures are used for storage. Building identification numbers are those specified in National Guard Bureau's Facility Inventory and Stationing Plan (NGB 1987). 


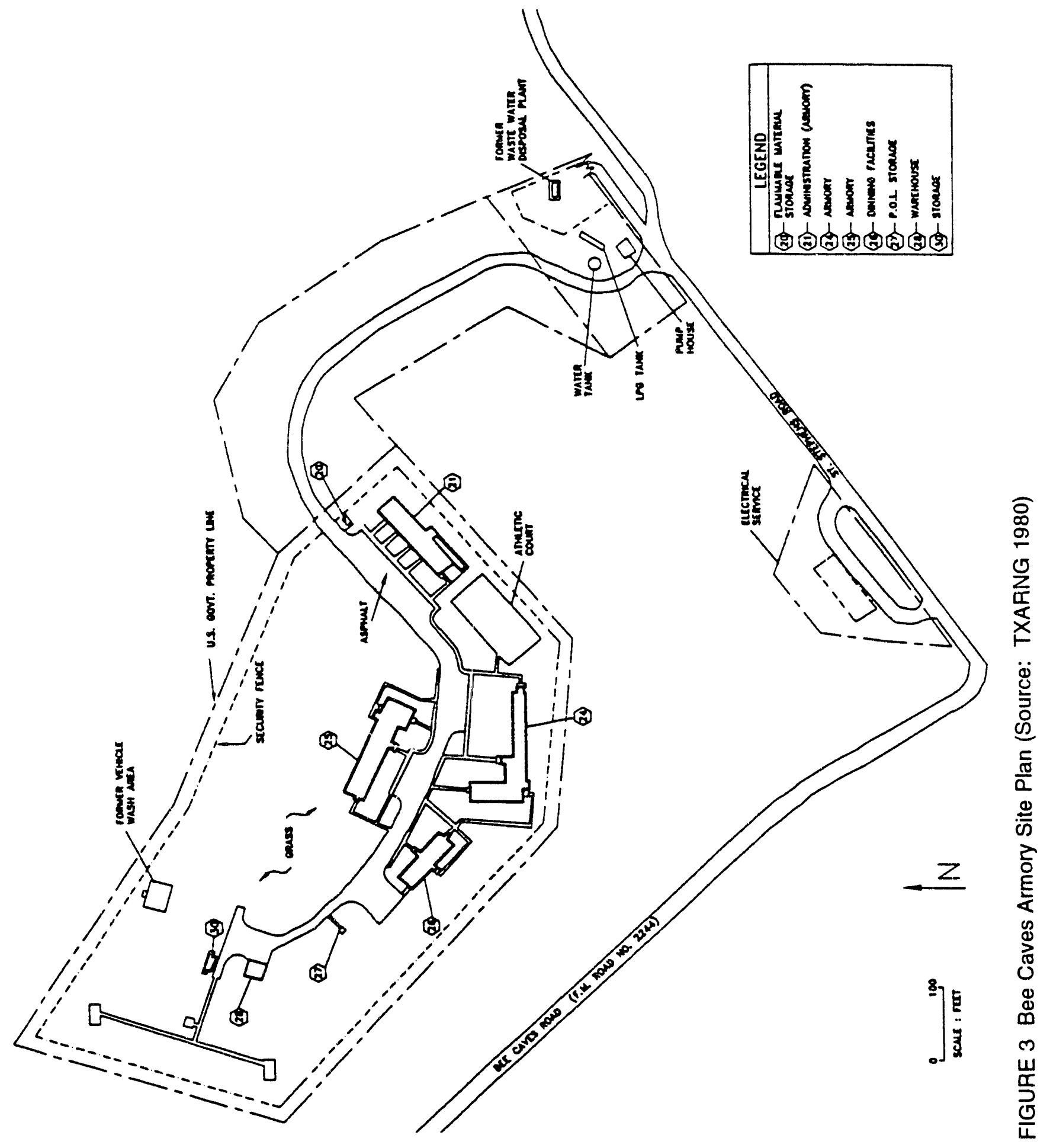


Building 20 is a single-room storage shed for lawn mowers and other groundskeeping equipment. Small quantities of gasoline for mowers and paint-related products are also stored. Water, heat, and air conditioning are not available to the building. During the former Nike activities, the $39-\mathrm{ft}^{2}$ building served as a sentry post or guard house.

Building 21 is a single-story structure consisting of offices, workrooms, storage, heater room, and latrine. During the former Nike activities, the $4,232-\mathrm{ft}^{2}$ building served as administrative headquarters.

Building 24 consists of classrooms, supply rooms, offices, a mechanical room, and a chapel. A former shower area has been converted to a photographic process dark rool. ?. During the former Nike activities, the 7,126- $\mathrm{ft}^{2}$ building served as a barracks.

Building 25 consists of two large rooms used for the materials service sections, store rooms, and offices. The building also contains a latrine and boiler room. During the former Nike activities, the 5,209- $\mathrm{ft}^{2}$ building served as a barracks.

Building 26 is the unit kitchen and dining area. A boiler room, pantry-storage rooms, and latrine are also available. During the former Nike activities, the 2,391- $\mathrm{ft}^{2}$ building also served in this capacity.

Building 27 is a single-room storage shed for small quantities of petroleum, oils, ind lubricants (POL). Water, heat, and air conditioning are not available to the building. During the former Nike activities, the $54-\mathrm{ft}^{2}$ building also served as the POL storage building.

Building 28 consists of a single, large, open space used as a warehouse, with one small office and a latrine. During the former Nike activities, the $819-\mathrm{ft}^{2}$ building contained the generator and frequency change equipment, removed when the Nike facility was deactivated. A 6,000-gal UST containing diesel fuel and located adjacent to the building served the generator.

Building 30 is a single, large, open space used for storage of nonhazardous materials. An enclosed, nonoperational heating/air conditioning system is present in the building. During the former Nike activities, the $367-\mathrm{ft}^{2}$ building served as an interconnecting corridor between the battery control van and the radar control van. Both of these structures were removed from the site during deactivation of the Nike operations. 


\subsubsection{Former Vehicle Wash Area}

Some wheeled vehicles (six to eight) are available for use by the site personnel. Vehicle maintenance and service are performed at nearby Camp Swift, located southeast of Austin. A vehicle wash area, approximately $25 \mathrm{ft} \times 25 \mathrm{ft}$, was located in the north portion of the ARNG property, with wash water running off to the surrounding ground. According to site personnel, the wash area was seldom used in years past, and use of the wash area has now been terminated (Dennis 1993). The former limited vehicle washing activity is dismissed as an environmentally sensitive operation because of its negligible potential impact to human health and the environment.

\subsubsection{Facility Sewage Treatment System}

In 1991, a low-pressure dosed (LPD) trench-type septic system was installed, replacing the existing waste water treatment system. The new septic system comprises two 4,314-gal singlecompartment septic tanks, one 1,250-gal pump tank with duplex pump system, and LPD trench drainfields containing 2,870 ft (linear) of trenches installed on 5-ft centers (Ellison 199C). The location and design of the new treatment system are depicted in Figures 4 and 5, respectively.

The capacity of the septic system was determined by two sewage flow calculations: (1) typical monthly water consumption and (2) water consumption during a period when a full contingent of personnel was present at the site for training. In the first calculation method, the estimated monthly water consumption for May 17 through June 16, 1988, was 34,300 gal, yielding a consumption of 1,147 gal per day. In the second calculation method, water consumption during the three-day training period of September 8 through September 11, 1989 , was $8,500 \mathrm{gal}$, yielding a maximum expected water consumption of 2,833 gal per day. To meet the maximum required design capacity, a drainfield area of $14,350 \mathrm{ft}^{2}$ and a septic tank volume of 8,628 gal were provided. A septic system depends on the filtration and adsorption properties of topsoil to cleanse the water. Generally, 3-6 ft of medium- to fine-textured soil with a permeability of 2-6 in./hr is desirable to ensure protection against pathogens. To compensate for the rock substrata present at the ARNG property, a 50\% overdesign of the drainfield area was installed. A description of soils in the vicinity is presented in Section 2.5.3.2.

The design of the abandoned waste water treatment system is discussed in Section 3.4. 


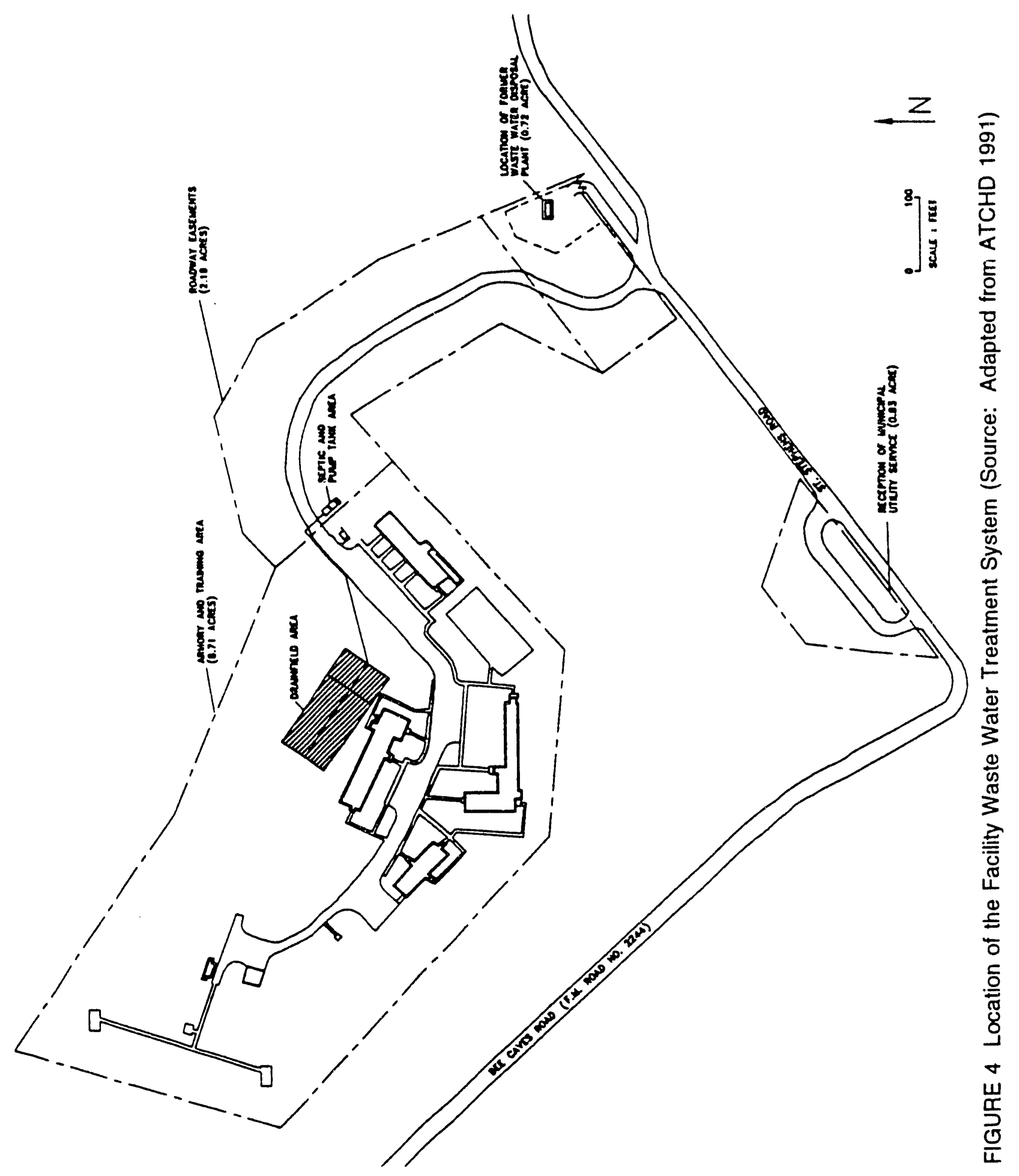




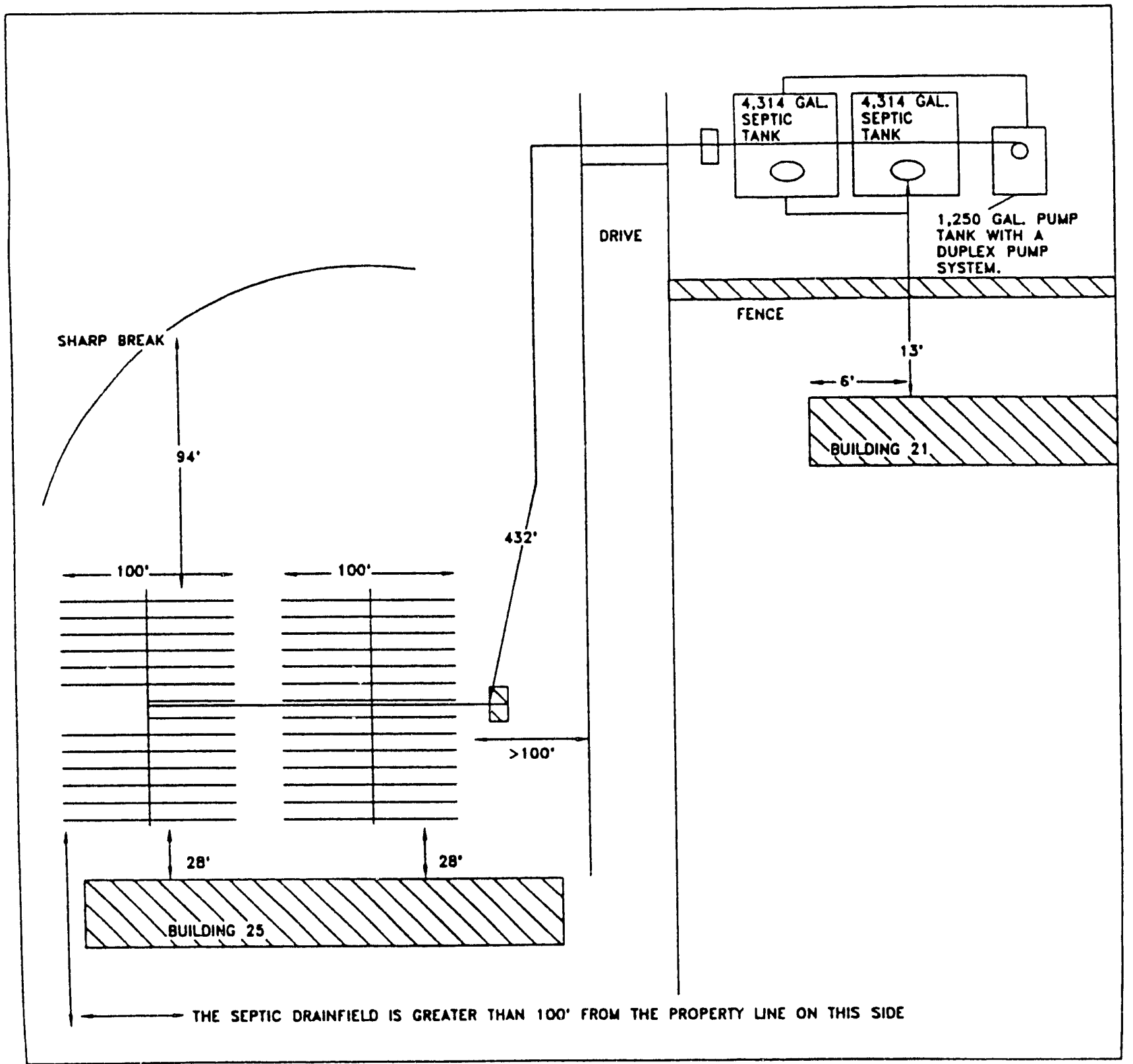

FIGURE 5 Design of the Facility Waste Water Treatment System (Source: Adapted from ATCHD 1991) 


\subsubsection{Utilities}

The reception point for municipal electrical service (City Electric of Austin) and the water service (Water District No. 10 Austin) is a 0.93-acre parcel of land near the intersection of Bee Caves Road and St. Stephens Road. A pump house located in the 0.72-acre parcel up the hill pumps water to a 20,000-gal storage tank. The property contains $2,616 \mathrm{ft}$ of water line. Building heating is provided by using liquid propane gas (LPG) fuel that is stored in an aboveground 3,500-gal tank. The property contains $1,498 \mathrm{ft}$ of gas line. The LPG tank, located in a secured fenced area, is regularly inspected and serviced by the provider (Southern Ohio Gas Company). Its use is not considered in this PA to be an ESO.

\subsection{Property History}

The Bee Caves ARNG property was originally developed in approximately 196() as one component in the U.S. Nike-Hercules Missile Defense System. The Bee Caves installation (NikeHercules Defense Site BG-80; so designated because of its location within the Bergstrom Defense area) is located about $0.5 \mathrm{mi}$ west of Austin; the Elroy, Texas, installation (Nike-Hercules Defense Site BG-40) is located about $10 \mathrm{mi}$ southeast of Austin. These two installations made up the Bergstrom Defense Area, with headquarters at Bergstrom Air Force Base (ESE 1984). Together these facilities provided protection from aerial attack for the greater Austin area. The IFC area of Defense Site BG-80 was located at the Bee Caves ARNG property. It contained all the radar. guidance, electronic, and communications equipment needed to identify incoming targets. launch the battery's missiles, and direct the missiles in flight. The exact location of the Missile Launch Area (MLA) of Defense Site BG-80 is unknown, although instrumentation limitations required that the control and launch areas be separated by a distance of at least $0.56 \mathrm{mi}$ and no more than $2.98 \mathrm{mi}$ (ESE 1984).

On July 1, 1966, the Texas National Guard received authorization from the Department of the Arriy to use the two excess Nike-Hercules Bases near Austin for armory purposes (Bishop 1965; Rochford 1966). The terms of the agreement stipulated use of the facilities for a period of one year, to be renewed annually. Activation of the Bee Caves facility by the ARNG occurred in May 1967 (Webster 1967). Under Amendment 1 to License DACA63-3-81-()5()2. which was accepted on May 28, 1985, and governs the Bee Caves ARNG property, use of that facility by the Texas National Guard was extended for 25 years, to June 30, 2015 (Starr 1985). 


\subsection{Permitting Status}

This installation has no ESOs that require RCRA permits, and no ESOs at this property are designated for CERCLA activities. The design and construction of the current sewage treatment system at the Bee Caves property was approved by the Austin-Travis County Health Department in June 1990 (Ellison 1990). On April 30, 1991, the Austin-Travis County Health Department issued a license to the Texas ARNG to operate the treatment facility (ATCHD 1991).

\subsection{Surrounding Environment and Land Use}

\subsubsection{Demographics and Land Use}

The Bee Caves Armory is located in Travis County in central Texas approximately $0.5 \mathrm{mi}$ west of the corporate boundary of the city of Austin. The surrounding area is high-value urban residential development, with some limited commercial ventures along Bee Caves Road. The Rob Roy Subdivision, to the north and east of the ARNG site, is an area of approximately 200 homes with an estimated population of 600. East of the site approximately 3-4 mi, as shown in Figure 6, are West Lake Hills (population 2,542) and Rollingwood (population 1,388). Austin has a population of 465,622 (Rand McNally 1992).

The growth of the city of Austin and development of major highways into the region have stimulated large-scale subdivision development. Through provision of water and sewer services, the city has directed most of this development along two north-south corridors following Interstate 35 and State Highway 183. As discussed in the following sections, much of the area west of the city is environmentally unsuitable for substantial residential development. In spite of the rugged appearance of the hill country in which the ARNG property is located, the ecology of the area is fragile. Rainfall is low, and soils are thin, resulting in a very low regenerative capacity. Residential development in the western region is scattered and relatively sparse. One area of residential development since approximately 1980 is the ravine adjacent to the ARNG property. Approximately 50 homes have been constructed there.

Because of its hilltop location, the Bee Caves site is considered to have high potential for development as residential property. In fact, during the development of the surrounding area in the 


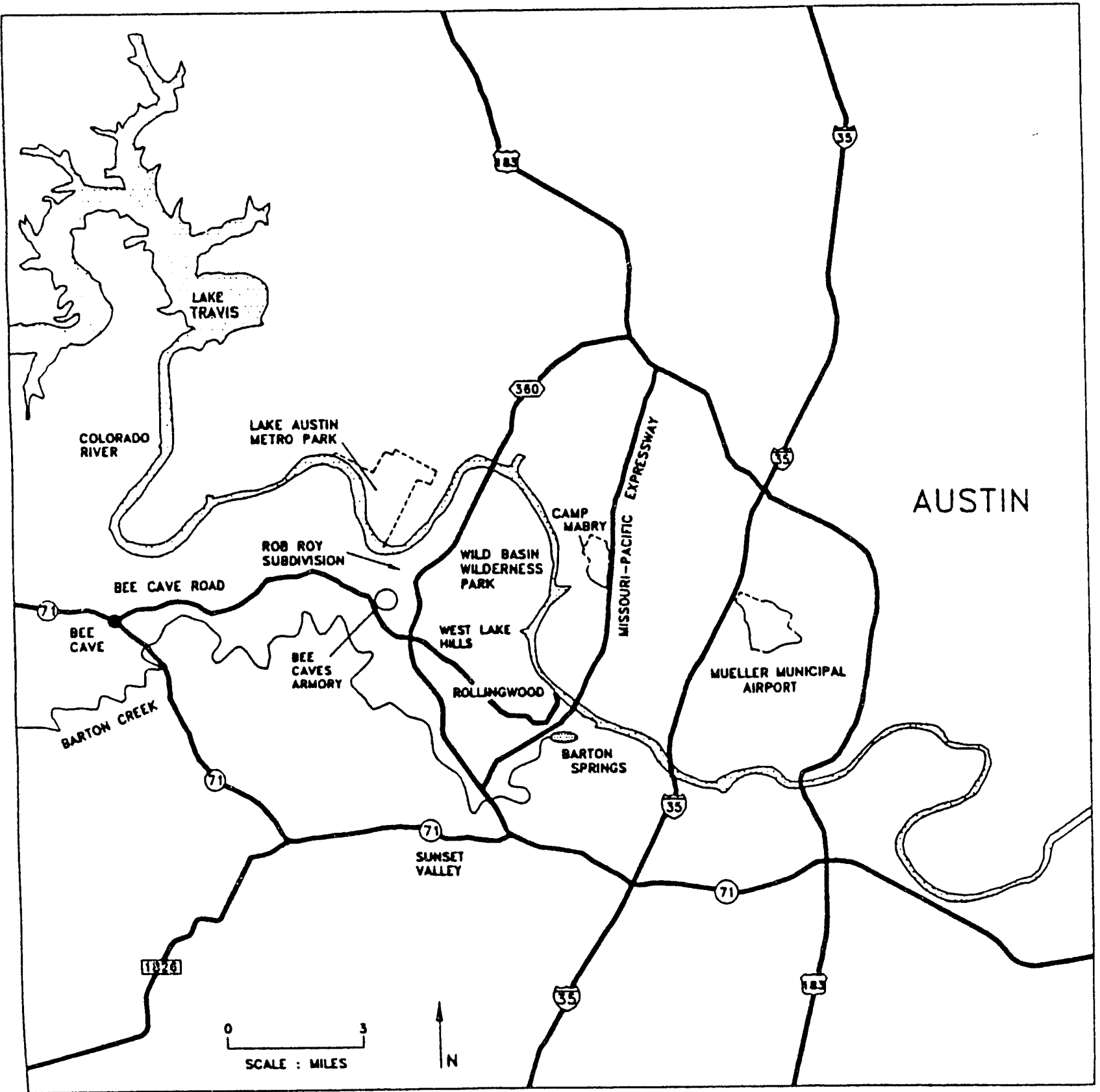

FIGURE 6 Vicinity of Bee Caves Armory (Source: Adapted from USGS 1988a, USGS 1988b) 
past decade, attempts have been made to obtain easements into the property. A 1977 request (Lloyd 1977) to connect the new housing development to the ARNG facility sanitary sewage system in use at that time was rejected by the Texas ARNG on grounds that the existing system could not accommodate added use without a corresponding increase in operating costs and, further, that state and federal funds appropriated for military purposes could not properly be used for private endeavors (Starr 1978a). A 1978 request (Bradley 1978) to construct a water tower on ARNG property was rejected as a hazard to flying aircraft (helicopters) and as being inconsistent with military purposes (Starr 1978b). A 1985 request for permission to install an 8-in. Water line through a portion of the ARNG property that would serve a planned 29-unit single-family residential development was approved (Cain 1985).

Approximately 1 mi north of the Bee Caves ARNG property flows the Colorado River, primary source of drinking water for the Austin region. Approximately $1 \mathrm{mi}$ south of the property flows Barton Creek. On the north bank of the Colorado River north of the ARNG property is the Lake Austin Metropolitan Park. North and northeast of the property (north of West Lake Hills) lies the Wild Basin Wilderness Park. Both areas are public parks and wildlife hatitats associated with the Lake Austin and Town Lake reservoir development projects. Further discussion of these sensitive environments is provided in Section 2.5.5.

\subsubsection{Climate}

The climate of Travis County is humid subtropical (NOAA 1988). Short, mild winters with temperatures below freezing occurring on average less than 25 days each year are followed by short springs and long, hot summers. Rather strong northerly winds accompanied by sharp drops in temperature, occasionally occur during the winter months in connection with cold fronts. Cold spells are usually of short duration, however, rarely lasting more than two days. Daytime temperatures in summer are high, but summer nights are usually pleasant with average daily minima in the low seventies. The mean maximum temperature for July is around $95^{\circ} \mathrm{F}$, and the mean minimum temperature for January is about $41^{\circ} \mathrm{F}$. The average length of the growing season or frost-free period is 270 days, lasting on average from March 3 to November 28.

Precipitation records furnished by the U.S. National Weather Service at Austin from 1900 through 1976 indicate an average annual precipitation of $33.5 \mathrm{in.} \mathrm{(Brune} \mathrm{1983).} \mathrm{The} \mathrm{maximum}$ officially recorded annual rainfall occurred in 1919 with 64.68 in. The minimum officially recorded annual rainfall in the period of record occurred in 1954 with $11.42 \mathrm{in}$. Monthly gross 
surface evaporation ranges from 2.3 in. in January to 9.2 in. in August. Average annual gross evaporation is 61.7 in.

Precipitation is distributed throughout the year, with the heaviest amou :ts occurring in late spring. A secondary rainfall peak occurs in September. Precipitation irom April through September usually results from thunderstorms, with fairly large amounts falling within short periods of time. Although thunderstorms and heavy rains have occurred in all months of the year, most of the winter precipitation occurs as light rain. Snow is insignificant as a source of moisture and usually melts as rapidly as it falls. The area may experience several seasons in succession with no measurable snowfall.

\subsubsection{Physiography, 3oils, ano' Surface Hydrology}

The following sections describe the local and regional surface physiography and hydrology (Brune 1983: DHUD 1981; Patterson 1963; Senger et al. 1984; Slade et al. 1986).

\subsubsection{Physiography}

Texas comprises four physiographic provinces: (1) the Basin and Range province, (2) the Great Plains province, (3) the Central Lowland, and (4) the Coastal Plain (Figure 7) (Patterson 1963). The Great Plains province covers the greater part of west-central and west Texas and comprises the High Plains (the relatively flat area of West Texas), the Edwards: Plateau, and the Central Texas section. The Coastal Plain occupies southeast Texas. A series of geologic fault zones defines the boundary between the Great Plains province and the Coastal Plain province. One of these zones, the Balcones Fault Zone, is a belt of northeast-trending normal faults extending over nine counties from kinney to Bell (Senger et al. 1984). The fault zone traverses Travis County, and the ARNG property is located approximately 2 mi west of the fault zone.

The predominant physiographic feature of Travis County is the Balcones Fault Zone, approximately 6 to $8 \mathrm{mi}$ wide. It marks the transition between the Edwards Plateau in the western portion of the county and the Blackland Prairie in the east. The Edwards Pl aau region is characterized by precipitous cliffs and ridgelines with scenic views. To the east are rolling plains. Topographically, the altitude above mean sea level in the county varies from approximately $1,350 \mathrm{ft}$ in the northwest corner to approximately $365 \mathrm{ft}$ in the bed of the Colorado River where it crosises the eastern boundary of the county. 


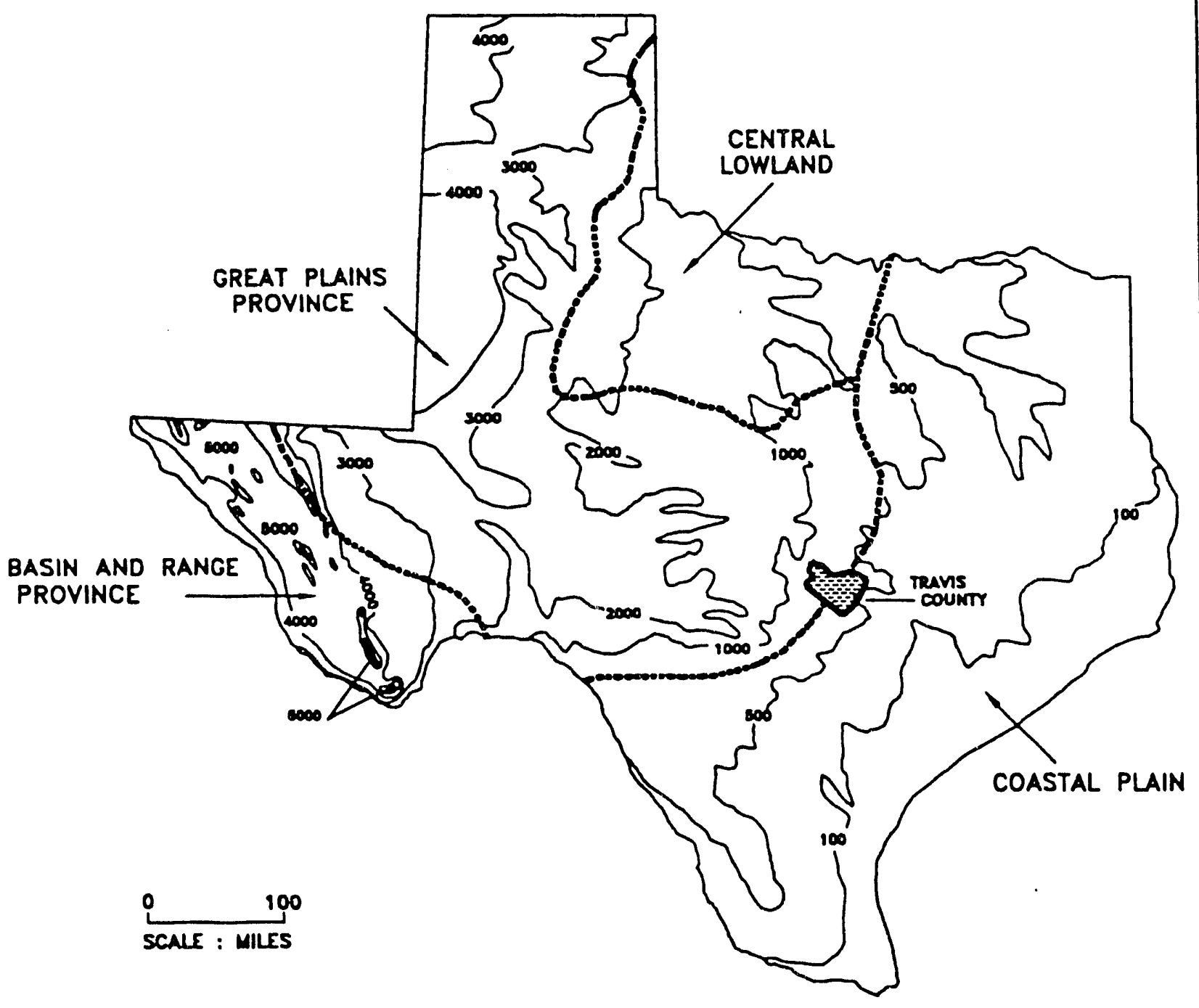

FIGURE 7 Major Physiographic Provinces of Texas (Source: Patterson 1963) 
The geologic formations of the Edwards Plateau and the Blackland Prairie differ. The gently eastward-dipping Cretaceous rocks were displaced by the extensive faulting, resulting in the juxtaposition of different types of rock exhibiting varying degrees of resistance to erosion. The differential erosion parallel to the numerous northeast-trending faults of the zone is evident in the diversity of vegetation supported on the outcrop. At some locations, the major creeks are entrenched into limestone valleys that have nearly vertical slopes (Slade et al. 1986). The primary significance of the fault zone lies in the development and recharge of the Edwards aquifer. The Balcones Fault Zone and the Edwards aquifer are discussed rurther in Section 2.5.4.

\subsubsection{Soils}

The soils that characterize the region are primarily related to their substrate (DHUD 1981). The Edwards Plateau, location of the ARNG property, consists of a hard or mixed limestone rock base, covered by a thin, gravelly, clay-loam topsoil. The Bracket, Speck, and Tarrant soil associations dominate. The Blackland Prairie to the east consists of clay and soft limestone rock covered by a thick topsoil of calcareous clays, silty clay, or clay-loam. The deep soils are dominated by the Houston Black-Heiden and Austin-Eddy associations. The central fault zone is difficult to characterize because of the geologic displacements. It forms the outcrop of the Edwards aquifer in the Travis County region of central Texas. The bedrock consists of hard to soft limestone with interbedded marl. Topsoils are typically dark brown, grayish brown, and reddish brown silty to clayey loams.

Topsoil in the vicinity of the ARNG property is typically less than $3 \mathrm{ft}$ thick with low permeability. Depth to bedrock for the Bracket soil series is generally 10-20 in.; permeability is 0.20-0.63 in./hr. Depth to bedrock for the Speck soil series is generally 14-18 in.; permeability is 0.06-0.20 in./hr. Depth to bedrock for the Tarrant soil series is generally only 4-14 in.; permeability is $0.06-0.20 \mathrm{in} . / \mathrm{hr}$. Once disturbed, this shallow topsoil on the steep slopes of the Edwards Plateau "Hill Country" in which the Bee Caves ARNG property is located is prone to erosion. In some locations on the steep slopes, washout of the shallow topsoils during heavy rainfall has exposed the underlying bedrock. 


\subsubsection{Surface Hydrology}

Numerous bodies of surface water are present in Travis County, as depicted in Figure 8 (Brune 1983). The Colorado River flows through the center of the county from northwest to southeast. A number of reservoirs have been built on this river for hydroelectric power generation, for flood control, and to provide a source of drinking water and recreation. The uppermost reservoir is Lake Travis, which backs up into Burnet County. The Mansfield Dam, completed in 1942, forms the reservoir whose surface area is 18,930 acres for an estimated capacity of $1,172,600$ acre-ft. The next reservoir downstream is Lake Austin, formed by the Tom Miller Dam completed in 1940. The surface area and capacity of the reservoir are 1,830 acres and 21,000 acre ft, respectively. Town Lake, formed by Longhorn Dam just downstream from Lake Austin, has a surface area of 416 acres and capacity of 3,520 acre-ft. Approximately 10 mi east of Austin is the Walter E. Long Lake. It has a surface area of 1,269 acres and a capacity of 33,940 acre-ft.

Several tributaries enter the Colorado River in Travis County. Near the western boundary of the county, the Pedernales River enters Lake Travis from the south. The chief tributaries entering from the north are Cow, Sandy, and Bull creeks. Tributaries from the south include the Bear, Slaughter, Williamson, Barton, and Onion creeks. Recharge to the Edwards aquifer occurs predominantly along these five major southern tributaries to the river (Slade et al. 1986) (Section 2.5.4.3). Barton Springs, widely known as a recreational center, discharges along Barton Creek a short distance above its mouth.

The Bee Caves ARNG property is located between the Colorado River to the north and Barton Creek to the south. East of the site lies the greater Austin area and Lake Austin and Town Lake. The city of Austin treats surface water from those two reservoirs as well as Barton Springs and distributes it to the entire surrounding area, including the ARNG property. Surface water provides the majority of water supplied.

\subsubsection{Groundwater and Hydrogeology}

The following sections describe the local and regional geology and groundwater (Baker et al. 1986; Brune 1983; Flores 1990; Senger et al. 1984; Slade et al. 1986; TWC 1989; TWC 1993; TWDB 1976). 
PA for Bee Caves Armory

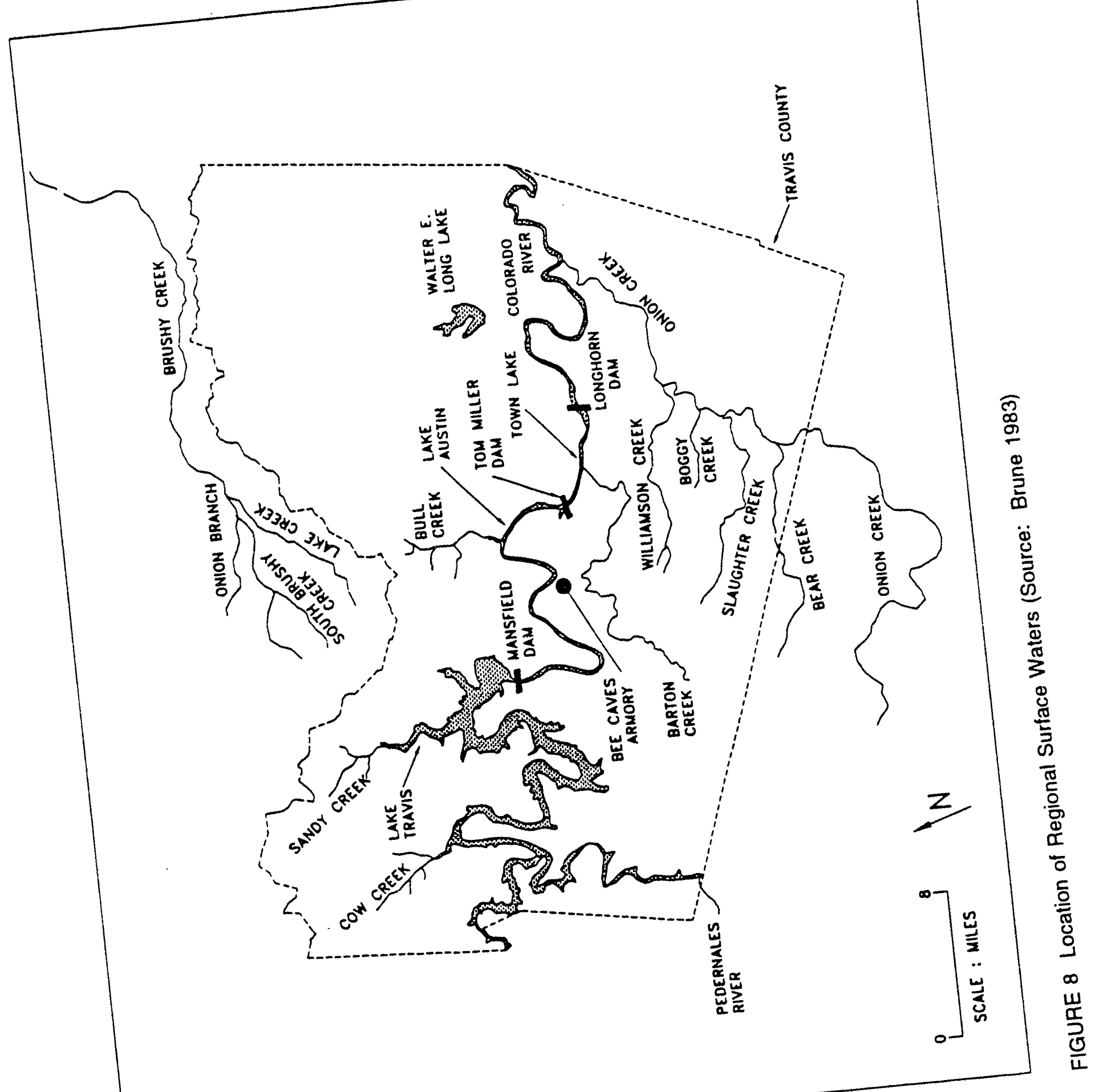




\subsubsection{Regional Geology}

The geologic history of central Texas, which includes Travis County and the area to the southeast, toward the Gulf of Mexico, is complex (Brune 1983). During Precambrian time when the sea extended northward into the region, limestone, sandstone, carbonaceous shales, and other marine sediments were deposited. This sedimentary basin existed during most of the Paleozoic era. Deposition in the basin was terminated during Pennsylvanian time, when the area to the west of Travis County was raised above sea level. Known as the Llano Uplift, this folding caused regional tilting to the west and extensive faulting through central Texas. Most of Texas became dry land as the seas retreated south toward the Gulf of Mexico. Then, at the beginning of the Cretaceous period, the sea advanced again from the south and east, eventually covering all of central Texas. This period is marked by a series of regressions and transgressions, resulting in the sequences of limestone, sandstone, and shale deposition evident in Travis County. The uplift continued, and the seas retreated south and east, marking the end of the Cretaceous period in central Texas. In Tertiary time, only the extreme eastern portion of the county, outside the immediate area of concern, was again invaded by the sea. During the Cenozoic era, in Miocene and Pliocene times, much readjustment of the previously deposited sediments occurred, resulting in extensive faulting. During Pleistocene time, the many river terraces and high gravel deposits were laid down upon the older sediments.

The stratigraphic units underlying Travis County are composed largely of limestones, chalk, shale, sand, and clay. Smaller amounts of gravel, silt, dolomite, gypsum, anhydrite, conglomerate, siltstone, and sandstone are also present. Figure 9 is a geologic section traversing Travis County from northwest to southeast (Brune 1983). The exposed geologic units are mainly of Cretaceous age. The Edwards Plateau, location of the ARNG property, consists of older Cretaceous rocks including the Walnut Clay and the underlying Glen Rose Limestone, covered by a thin, gravelly, clay-loam topsoil. East of the central Balcones Fault Zone is the Blackland Prairie consisting of younger rocks and clays including the Navarro and Taylor groups, the Austin Chalk, the Eagle Ford Group, the Buda Limestone, and the Del Rio Clay, covered by a thick topsoil of calcareous clays, silty clay, or clay-loam. Underlying the Del Rio Clay are the Georgetown and Edwards formations. Underlying the Glen Rose Limestone on both sides of the Balcones Fault Zone is the Travis Peak Formation, consisting of limestone, sand, and shale. 


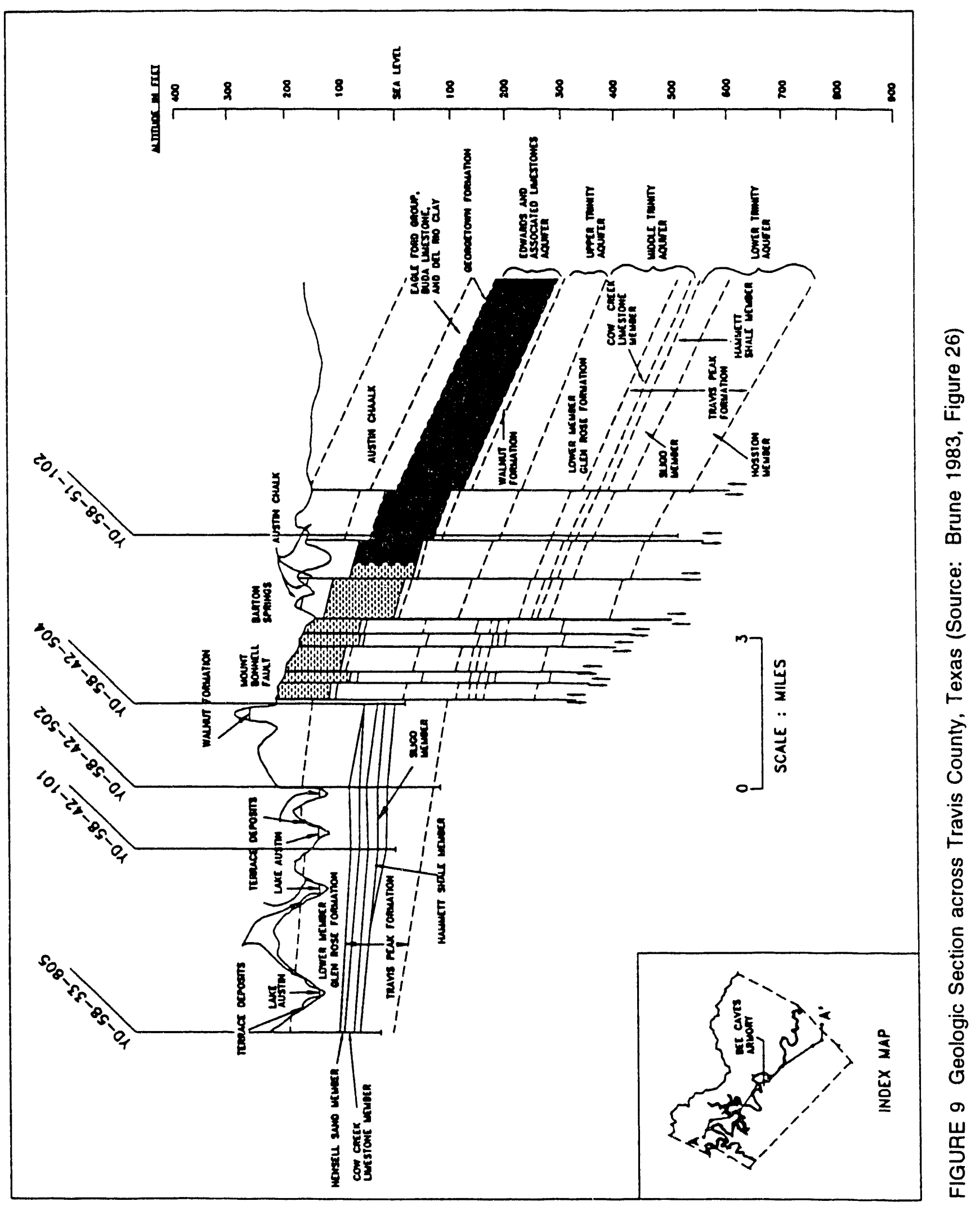


The Travis Peak Formation is composed of the Hosston, the Sligo, Hammett Shale, Cow Creek Limestone, and Hensell Sand members. The Hosston is composed of pebbly, sandy conglomerate, sometimes containing boulders more than $1 \mathrm{ft}$ in diameter, cemented with calcite or silica cement. Various colored shales and occasionally streaks of limestone are also present. The Hosston is sometimes called the "lower Trinity sand" or the "second Trinity sand" by water well drillers. The Hosston varies in thickness in downdip areas from about $150 \mathrm{ft}$ in northwest Travis County to $800 \mathrm{ft}$ in the southeast. The Sligo member exists only in the southeastern portion of the county, where it attains a maximum thickness of about $300 \mathrm{ft}$. This transitional unit grades upward into a fossiliferous, dolomitic limestone that is crystalline to chalky. The Hammett Shale member of the Travis Peak Formation is the result of the second transgressive marine phase. It is predominantly a shale, gray to buff in color, with some dolomitic limestone in the upper part. The unit has a relatively constant thickness of about $60 \mathrm{ft}$ throughout the county. The Cow Creek Limestone overlies the Hammett Shale and is composed of cream-to-tan colored, massive, fossiliferous limestone with some gypsum or anhydrite beds. Thickness of the Cow Creek ranges from $50 \mathrm{ft}$ in the northwest part of the county to $100 \mathrm{ft}$ in the southeast. The upper member of the Travis Peak Formation is the Hensell Sand, often called the "first Trinity sand" or "upper Trinity sand." It consists of poorly sorted, cross-bedded conglomerate cemented with silica and varicolored sand, sandstones, silts, clays, and shales. The grain size of the sand decreases to the southeast, grading into sandy limestone and dolomite beds that are difficult to distinguish from the overlying Glen Rose Formation (Brune 1983).

The lower member of the Glen Rose Formation consists of massive, fossiliferous limestone and dolomite in the basal part, grading upward into thin beds of limestone, shale, marl, anhydrite, and gypsum. The beds of gypsum are usually partially dissolved, leaving solution channels. Over a wide portion of central Texas, an approximately 1 - $\mathrm{ft}$-thick accumulation of the fossil clam Corbula martinae forms an iron-stained ledge separating the lower and upper members of the Glen Rose Formation. Subsurface thickness of the lower member increases from about $130 \mathrm{ft}$ in northwestern Travis County to $330 \mathrm{ft}$ in the southeast (Brune 1983).

The upper member of the Glen Rose Formation consists of shale and marl alternating with thin beds of impure limestone and dolomite. Beds of gypsum and anhydrite may occur, but usually these have been dissolved, leaving solution channels. Gypsum and anhydrite are not known to occur in surface outcrops and usually not above the water table. The upper member of the Glen Rose Formation outcrops in the northwestern two-thirds of the county. Its downdip thickness ranges from $220 \mathrm{ft}$ in the northwestern part of the county to about $600 \mathrm{ft}$ in the southeast. 
The upper $100 \mathrm{ft}$ contains much weathered. soft, porous dolomite and burrowed limestone; hence, it forms gentle slopes and has many springs (Brune 1983).

The various members of the Walnut Clay combine to make up a gray to tan, soft to very hard limestone. The formation consists of fine- to medium-grained fossiliferous limestones with layers of fine-grained marl, marly limestone, clays, and nodular limestone. The formation yields little or no water (Flores 1990).

The Edwards Limestone outcrops extensively within the Balcones Fault Zone east of the Mount Bonnel Fault. The formation also outcrops northward into Williamson and Bell counties. In the subsurface, the Edwards consists of 200 to $360 \mathrm{ft}$ of brittle, thick-bedded to massive limestone, commonly dolomite. containing minor beds of shale, clay, and siliceous limestone. Beds of chert and flint are common. Several solution-collapse zones in the Edwards Limestone represent former beds of gypsum that have been removed by solution. and interconnected voids from which shell material has been dissolved are common (Brune 1983).

The Georgetown Formation is a nodular limestone, usually gray to tan, massive, and interbedded with layers of marl or marly shale. It is fossiliferous, commonly contains burrows filled with fossil fragments, and also contains some minor solution zones. Downdip thicknesses of the formation range from 40 to $110 \mathrm{ft}$. However, the Georgetown and Edwards Formations are seldom differentiated by drillers in the area (Flores 1990).

The Del Rio Clay is a greenish-gray to olive-brown, selenitic, calcareous, pyritic, and fossiliferous clay. The confining clay obtains a maximum thickness of $85 \mathrm{ft}$ within the study area (Flores 1990).

The younger rocks of the Blackland Prairie east of the Balcones Fault Zone (i.e., the Eagle Ford, Austin, Taylor and Navarro Groups) consist predominantly of marl, shale, limestone, and igneous rocks.

\subsubsection{Local lieology}

Well YD-58-42-401 is located approximately 1 mi south of the ARNG property. This, public supply water well was drilled in 1950 to a depth of $690 \mathrm{ft}$ into the Hosston Member of the Travis Peak Formation (Brune 1983). In 1951, the well was deepened from 690 to $716 \mathrm{ft}$. The 
driller's log of the well describes the local geology (Table 2) (TWDB 1976). The surface elevation of the well is $820 \mathrm{ft}$. The well first penetrates the upper Glen Rose Formation for approximately $200 \mathrm{ft}$. The highly fossiliferous layer encountered at $190 \mathrm{ft}$ probably marks the transition to the lower Glen Rose. The upper sand of the Travis Peak Formation is not noted, but the massive clay unit is probably the Hammett Shale. The well produces from the lower Trinity aquifer.

\subsubsection{Regional Groundwater}

Two major aquifers provide groundwater resources in Travis County: the Trinity Group aquifer and the Edwards aquifer (TWDB 1976). An overview of the hydrogeologic framework within Travis County is depicted in Figure 10 (Flores 1990).

The entire study area is underlain by the Trinity aquifer. Because of markedly different hydrologic relationships, the water-bearing rocks of the Trinity Group aquifer are divided into three aquifer units: (1) the lower Trinity aquifer consisting of the Sligo and Hosston members of

TABLE 2 Driller's Log of Well YD-58-42-401, near the Bee Caves ARNG Property

\begin{tabular}{lrr}
\hline \multicolumn{1}{c}{ Description of Soil/Rock } & $\begin{array}{c}\text { Thickness } \\
(\mathrm{ft})\end{array}$ & $\begin{array}{c}\text { Depth } \\
(\mathrm{ft})\end{array}$ \\
\hline & & \\
Topsoil & 10 & 10 \\
Limestone, hard, white & 40 & 50 \\
Limestone, pale tan, compact, fairly hard, sugary & 90 & 140 \\
Limestone, white, soft & 40 & 180 \\
Marl, soft & 10 & 190 \\
Limestone, white, many shells & 20 & 210 \\
Limestone, soft, nodular, marly & 100 & 310 \\
Limestone, pale tan, sugary & 30 & 340 \\
Limestone, white & 10 & 350 \\
Limestone, hard, white, nodular & 20 & 370 \\
Limestone, hard, white & 150 & 520 \\
No record & 35 & 555 \\
Limestone, hard & 10 & 565 \\
Limestone, hard, grayish-tan, sugary & 15 & 580 \\
Limestone, grayish-tan, crumbly & 10 & 550 \\
Clay, gray, massive & 30 & 620 \\
Limestone, hard, sugary & 70 & 690 \\
& & \\
\hline
\end{tabular}

Source: TWDB 1976. 
PA for Bee Caves Armory

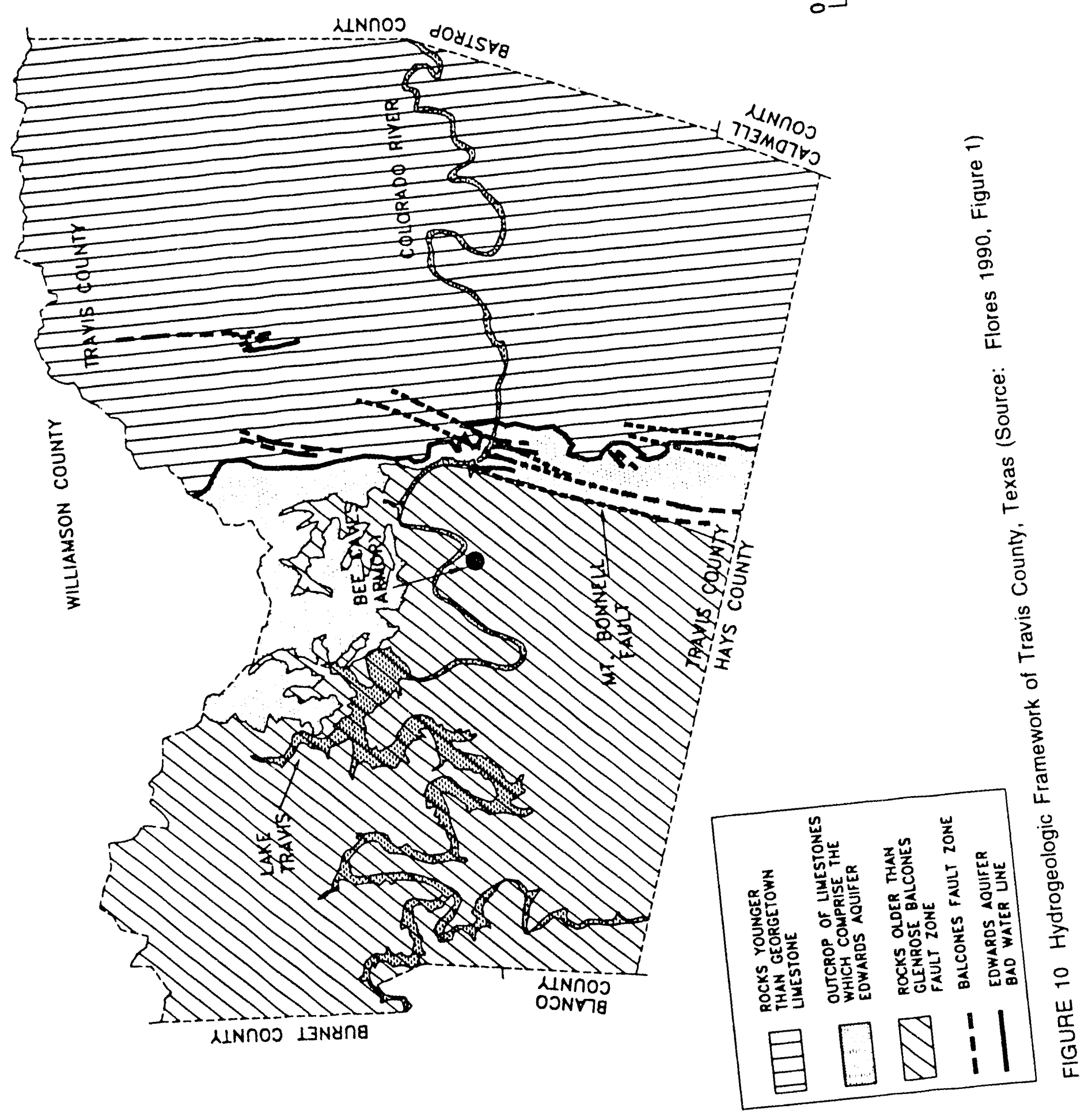


the Travis Peak Formation, (2) the middle Trinity aquifer consisting of the lower member of the Glen Rose Formation and the Hensell Sand and Cow Creek Limestone members of the Travis Creek Formation, and (3) the upper Trinity aquifer consisting of the upper member of the Glen Rose Formation and the Paluxy Formation. In the immediate area of the ARNG property, the upper Trinity aquifer is not present. The Hammett Shale Member of the Travis Peak Formation acts as a hydrologic barrier separating the lower and middle Trinity aquifers (Brune 1983). Total thickness of the lower Trinity aquifer ranges from only a few feet in northwestern Travis County to more than $1,000 \mathrm{ft}$ in the downdip area in the southeast. Thickness of the middle Trinity varies from approximately $300 \mathrm{ft}$ to more than $450 \mathrm{ft}$ along the same northwest-to-southeast geologic section. The beds of the lower and middle Trinity dip east-southeast at rates ranging from 15 to $320 \mathrm{ft}$ per mile.

Recharge to the Trinity Group aquifer is derived primarily from rainfall on the outcrop, as well as recharge from underflow, vertical leakage and seepage from lakes and streams. The Glen Rose Formation and the Hensell Sand Member of the Travis Peak Formation outcrop over the majority of the western portion of Travis County; therefore, these units receive the maximum recharge. Groundwater in the Trinity Group aquifer moves slowly downdip to the south and eastsoutheast toward lower elevations. Permeability varies from approximately 4.8 to 32 gal per day per square foot. Water level measurements indicate that the hydraulic gradient of the potentiometric surface is about 5-100 $\mathrm{ft}$ per mile (Brune 1983).

The Edwards aquifer exists in the middle portion of Travis County (east of the ARNG property) as a narrow and shallow area paralleling the Balcones Fault Zone (Senger et al. 1984; Flores 1990). The Mt. Bonnell fault, the largest fault along the western boundary of the fault zone, marks the western boundary of the aquifer. To the east, as identified in Figures 9 and 10, the boundary of the aquifer is marked by a "bad water line," beyond which the groundwater contains a high level of total dissolved solids.

The vertical cracks and fissures associated with the fault activity allowed the aquifer to form by providing a pathway for large amounts of groundwater to move toward discharge points at lower elevations within the bottoms of the incised stream valleys. Cavern porosity was created along vertical fractures and horizontal bedding planes. After discharge sites were established, a continuously circulating groundwater flow system developed. Today, recharge to the Edwards aquifer occurs predominantly along five major creeks flowing south of the ARNG property. These watersheds and their respective annual recharges to the aquifer are (1) Onion Creek, 34\%; (2) Barton Creek, 28\%; (3) Bear Creek, 20\%; (4) Slaughter Creek, 12\%; and (5) Williamson 
Creek, 6\%. Precipitation in the fault zone runs into the creeks, which then lose up to $100 \%$ of low-flow water to the aquifer (Senger et al. 1984). Although speculative, the "bad water line" in the Edwards aquifer-Balcones Fault Zone has been interpreted as the eastern extent of the groundwater circulation flow system. That is, as groundwater movement into the deeper, less permeable sections of the Edwards Formation became largely restricted, solution channels into the limestone were not formed, and the extent of the groundwater flow system was limited (Senger et al. 1984).

In the northeastern portion of Travis County, the Edwards aquifer is approximately 300 ft thick (Senger et al. 1984). The dip of the Edwards aquifer is to the east-southeast (toward Hays County) at a rate of 50-100 ft per mile. South of Travis County, the Edwards aquifer is approximately 400 ft thick. Coefficients for the Edwards aquifer vary greatly because of the nature of the aquifer. Flow is primarily through the cavities and caves associated with faults, fractures, and joints, and secondarily through porous media within the limestone (Slade et al. 1986). Permeability varies from 8.7 to $877 \mathrm{gal} / \mathrm{day} / \mathrm{ft}^{2}$. Well yields vary from small ( 10 to $30 \mathrm{gal} / \mathrm{min}$ ) to large (over $300 \mathrm{gal} / \mathrm{min}$ ), depending on the location of the well with respect to one of the solution zones.

\subsubsection{Local Groundwater}

Groundwater is used by residents or communities away from the surface water resources of the Colorado River, including Lake Travis, Lake Austin, and Town Lake. Numerous wells have been drilled in past years in the immediate area surrounding the ARNG property, as shown in Figure 11 (TWC 1993; TWDB 1976). Table 3 describes water wells within an approximate 4-mi radius of the property. As the city of Austin has expanded its water supply network toward the Bee Caves facility, use of some of the domestic wells has probably been discontinued.

Groundwater flow direction is to the east-southeast (DHUD 1981). Wells to the eastsoutheast of the Bee Caves ARNG property are in the 500 and 800 series (Figure 11, Table 3). Wells in the 500 series are located at an average elevation of $838 \mathrm{ft}$ above mean sea level. The water level in these wells is at an average depth of $299 \mathrm{ft}$ below the land surface. Wells in the 800 series are located at an average elevation of $738 \mathrm{ft}$ above mean sea level. The water level in these wells is at an average depth of $217 \mathrm{ft}$ below the land surface. 


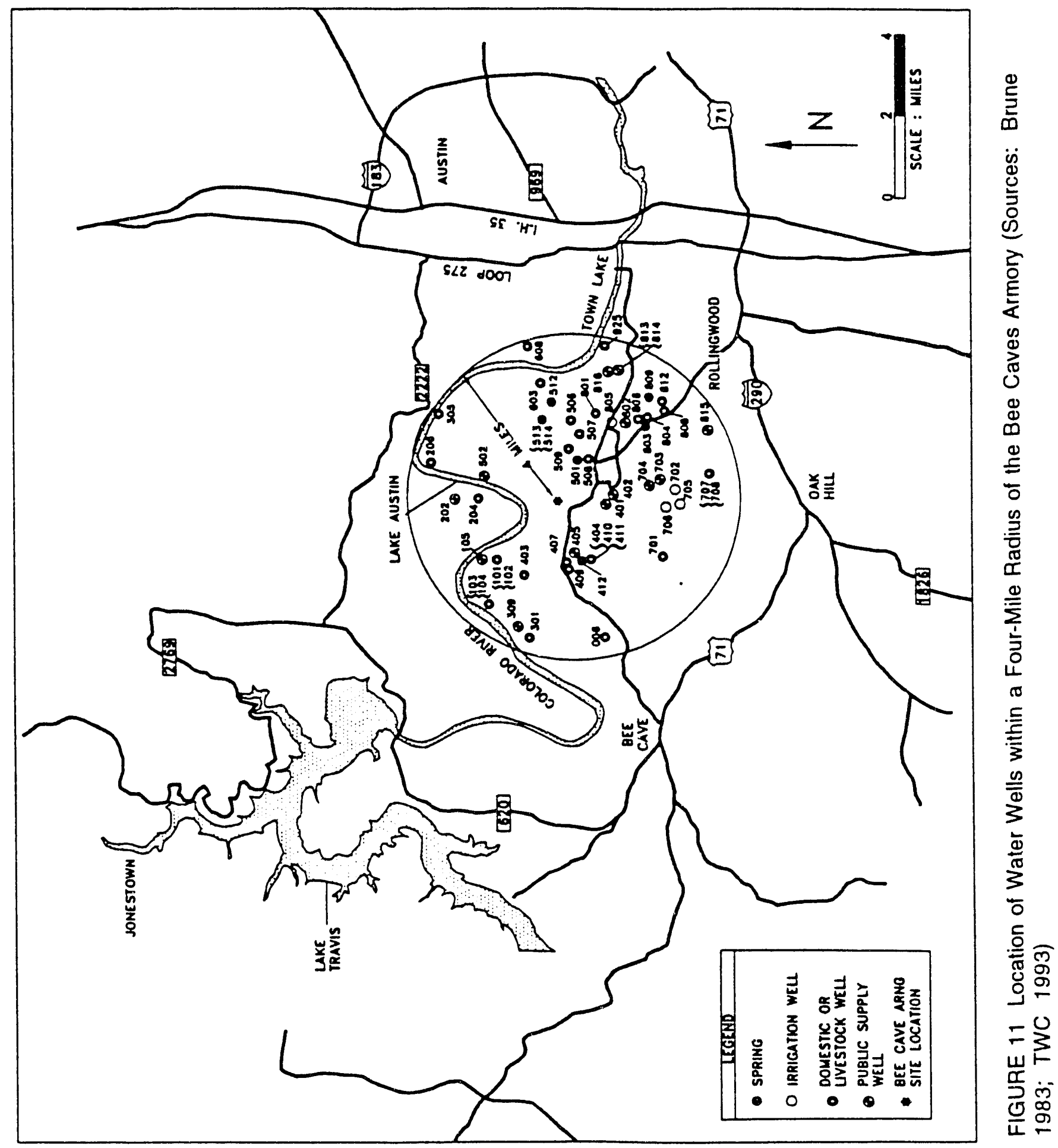


TABLE 3 Water Wells in the Vicinity of the Bee Caves Armorya

\begin{tabular}{|c|c|c|c|c|c|c|}
\hline Well ID & Year & $\begin{array}{c}\text { Depth of } \\
\text { Well } \\
(f t)\end{array}$ & $\begin{array}{c}\text { Altitude } \\
\text { of Land } \\
\text { Surface } \\
(f t)\end{array}$ & $\begin{array}{c}\text { Depth } \\
\text { below } \\
\text { Surfaceb } \\
(f t)\end{array}$ & $\begin{array}{c}\text { Water- } \\
\text { Bearing } \\
\text { Unit }\end{array}$ & $\begin{array}{l}\text { Use of } \\
\text { Water }\end{array}$ \\
\hline \multicolumn{7}{|l|}{ YD - } \\
\hline $58-41-006$ & 1988 & 870 & 480 & $\cdots$ & Kcgrl & $D$ \\
\hline 301 & 1967 & 500 & 640 & 139 & Kcho & D \\
\hline 309 & 1970 & 480 & 630 & 101 & Kcho & $P$ \\
\hline $58-42-101$ & 1966 & 499 & 520 & 31 & $\mathrm{Kcgr}$ & $D$ \\
\hline 102 & $i \sim 59$ & 490 & 500 & 10 & Kcho & D \\
\hline 103 & 1950 & 466 & 640 & 157 & Kcho & D \\
\hline 104 & 1968 & 361 & 530 & 29 & Kcho & $D$ \\
\hline 105 & 1963 & 60 & 497 & 25 & Qter & $P$ \\
\hline 202 & 1965 & 651 & 660 & 162 & Kcho & $P$ \\
\hline 204 & 1968 & 777 & 520 & 68 & Kcgrl & $D$ \\
\hline 206 & 1967 & 305 & 550 & $1: 3$ & Kche & $D$ \\
\hline 305 & 1967 & $: 90$ & 500 & $\ldots$ & $\mathrm{Kcgr}$ & $D$ \\
\hline 401 & 1950 & 716 & 820 & 239 & Kcho & $\mathrm{P}$ \\
\hline 402 & 1962 & 330 & 830 & 274 & Kcho & $\mathrm{P}$ \\
\hline 403 & 1969 & 372 & 620 & 185 & Kcgr & $D$ \\
\hline 404 & 1970 & 375 & 850 & 90 & $\mathrm{Kcgr}$ & $D$ \\
\hline 405 & 1967 & 840 & 880 & 350 & Kcho & $\mathrm{P}$ \\
\hline 407 & 1941 & 417 & 843 & $\ldots$ & $\mathrm{Kcgr}$ & $D$ \\
\hline 409 & 1974 & 550 & 860 & $\ldots$ & Kche & $D$ \\
\hline 410 & 1976 & $8 \cap 0$ & 840 & $\ldots$ & Kcho & $D$ \\
\hline 411 & 1976 & 800 & 835 & $\ldots$ & Kcho & $D$ \\
\hline 502 & 1949 & 1015 & 753 & 234 & Kcho & $P$ \\
\hline 506 & 1950 & 938 & 872 & $\cdots$ & Kcho & $D$ \\
\hline 507 & 1955 & 1045 & 880 & 320 & Kcho & $D$ \\
\hline 508 & 1954 & 495 & 880 & 342 & Kcgrl & $D$ \\
\hline 509 & 1942 & 627 & 800 & $\ldots$ & Kcgrl & $D$ \\
\hline 512 & $\cdots$ & Srring & 510 & $\ldots$ & Kcgru & $P$ \\
\hline 513 & $\cdots$ & Spring & 505 & $\ldots$ & Kcgru & $P$ \\
\hline 514 & $\ldots$ & Spring & 505 & $\ldots$ & Kcgru & $P$ \\
\hline 603 & 1963 & 400 & 680 & 222 & Kcgrl & $D$ \\
\hline 608 & 1939 & 145 & 540 & 101 & Kce & $D$ \\
\hline 701 & 1931 & 900 & 845 & 242 & Kcho & $D, S$ \\
\hline 702 & 1972 & 560 & 620 & 55 & Kcho & $\operatorname{lrr}$ \\
\hline 703 & 1972 & 620 & 680 & 164 & Kcho & $P$ \\
\hline 704 & 1972 & 740 & 810 & 264 & Kcho & $P$ \\
\hline 705 & 1972 & 525 & 630 & 46 & Kcho & $\operatorname{Irr}$ \\
\hline 706 & 1972 & 530 & 660 & 55 & Kcho & $\operatorname{lrr}$ \\
\hline 707 & 1930 & 420 & 840 & $\ldots$ & Kcgrl & $S$ \\
\hline 708 & 1961 & 485 & 910 & 19 & Kcgrl & $D$ \\
\hline 801 & 1955 & 846 & 760 & 180 & Kcho & $D, S$ \\
\hline 802 & 1946 & 1043 & 740 & 193 & Kchr & $P$ \\
\hline
\end{tabular}


TABLE 3 (Cont.)

\begin{tabular}{|c|c|c|c|c|c|c|}
\hline Well ID & Year & $\begin{array}{c}\text { Depth of } \\
\text { Well } \\
(f t)\end{array}$ & $\begin{array}{c}\text { Altitude } \\
\text { of Land } \\
\text { Surface } \\
(f t)\end{array}$ & $\begin{array}{c}\text { Depth } \\
\text { below } \\
\text { Surfaceb } \\
(f t)\end{array}$ & $\begin{array}{c}\text { Water } \\
\text { Bearing } \\
\text { Unit }\end{array}$ & $\begin{array}{l}\text { Use of } \\
\text { Water }\end{array}$ \\
\hline \multicolumn{7}{|l|}{ YD - } \\
\hline $58-42-803$ & 1955 & 897 & 760 & 208 & Kcgrl & D \\
\hline 804 & 1956 & 1035 & 750 & 240 & $\mathrm{Kcgrl}$ & $D$ \\
\hline 805 & 1954 & 876 & 770 & 184 & Kcho & $\operatorname{Irr}$ \\
\hline 806 & 1967 & 1130 & 800 & 200 & Kcho & $D$ \\
\hline 808 & 1956 & 638 & 720 & $\ldots$ & $\mathrm{Kcgr}$ & $D$ \\
\hline 809 & 1949 & 340 & 720 & 286 & Kce & $D, S$ \\
\hline 812 & 1958 & 375 & 745 & 277 & Kce & $D$ \\
\hline 813 & $\cdots$ & 300 & 660 & 217 & Kce & $P$ \\
\hline 814 & $\ldots$ & 300 & 660 & 214 & Kce & $P$ \\
\hline 815 & 1952 & 516 & 751 & 198 & Kce & $P,|r|$ \\
\hline 816 & 1964 & 290 & 640 & $\cdots$ & Kce & $P$ \\
\hline 925 & 1975 & 180 & 670 & 143 & Kce & $D$ \\
\hline
\end{tabular}

a Explanation of abbreviations:

$D=$ Domestic

Irr = Irrigation

Kce $=\mathrm{Edwards}$ and associated limestones

$\mathrm{Kcgrl}=$ Lower member of the Glen Rose Limestone

Kcgru = Upper member of the Glen Rose Limestone

$\mathrm{Kcho}=$ Hosston member of the Travis Peak Formation

$\mathrm{P}=$ Public supply

Qter $=$ Terrace deposits

$S=$ Livestock

b Water levels were taken on various dates.

Sources: Brune 1983; TWC 1993. 


\subsubsection{Sensitive Environments}

The vicinity of the Bee Caves ARNG property is an area of great natural diversity, encompassing portions of the Blackland Prairie, the precipitous Balcones Escarpment, and the rocky hills of the Edwards Plateau. The Wild Basin Wilderness Park and the Lake Austin Park to the north are protected areas with significant scientific, aesthetic, and recreational value. No direct surface water pathway flows to these protected wilderness areas from the ARNG property.

Woodland vegetation occurs on the steep hillsides and canyons of the Edwards Plateau and major drainage valleys. The general inaccessibility of the area has slowed the rate of urbanization. Upland woodlands are characterized by Spanish oak (Quercus texana), mountain live oak (Quercus fusiformis), ashe juniper (Juniperus ashei), and cedar elm (Ulmus crassifolia). Although they are abundant in other regions of the state, several plants are considered to be threatened or endangered in the Austin area. None are listed by the U.S. Fish and Wildlife Service (FWS) as being protected from disturbance; moreover, none of these species as listed in Table 4 are protected by the State of Texas Parks and Wildlife Department (TPWD) (DHUD 1981).

Common woodland animal species include sharp-shinned hawk, Cooper's hawk, barred owl, red-headed woodpecker, yellow-bellied sapsucker, golden-fronted woodpecker, vermilion flycatcher, wood thrush, ruby-crowned kinglet, tufted titmouse, Carolina chickadee, several species of wood warblers, fox sparrow, song sparrow, white-tailed deer, eastern fox squirrel, gray fox, eastern cottontail, fulvous harvest mouse, southern gray tree frog, green treefrog, Strecker's chorus frog, eastern and western box turtle, green anole, ground skink, eastern hognosed snake, garter and ribbon snakes, Texas coral snake, and copperhead. Several animal species listed by the FWS as endangered or threatened, or by the TPWD as protected nongame species, may potentially be found in the vicinity of the ARNG property. These species are listed in Table 5. The southern bald eagle, arctic peregrine falcon, interior least tern, and whooping crane are endangered species that migrate over the area but do not reside in the area at the present time. The white-faced ibis and osprey may be found in large bodies of water (not present on the ARNG property). In the spring, the golden-cheeked warbler nests in mature juniper trees on the Edwards Plateau. The endangered black-capped vireo is known to inhabit areas east, south, and west of the site, within a 3-mi radius. The TPWD also protects the Texas horned lizard and Mexican milk snake, both of which may be found in the greater study area (DHUD 1981). 


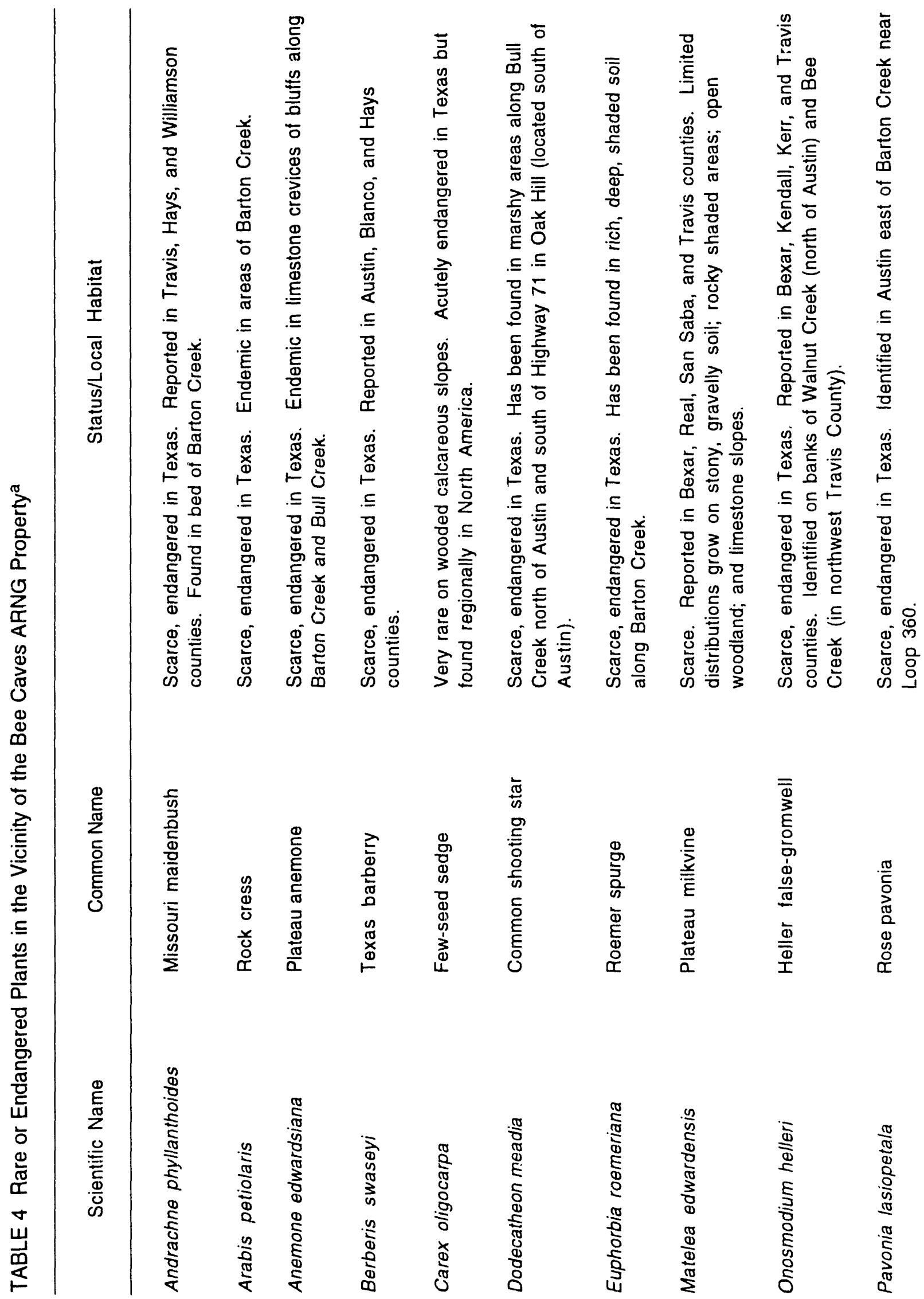




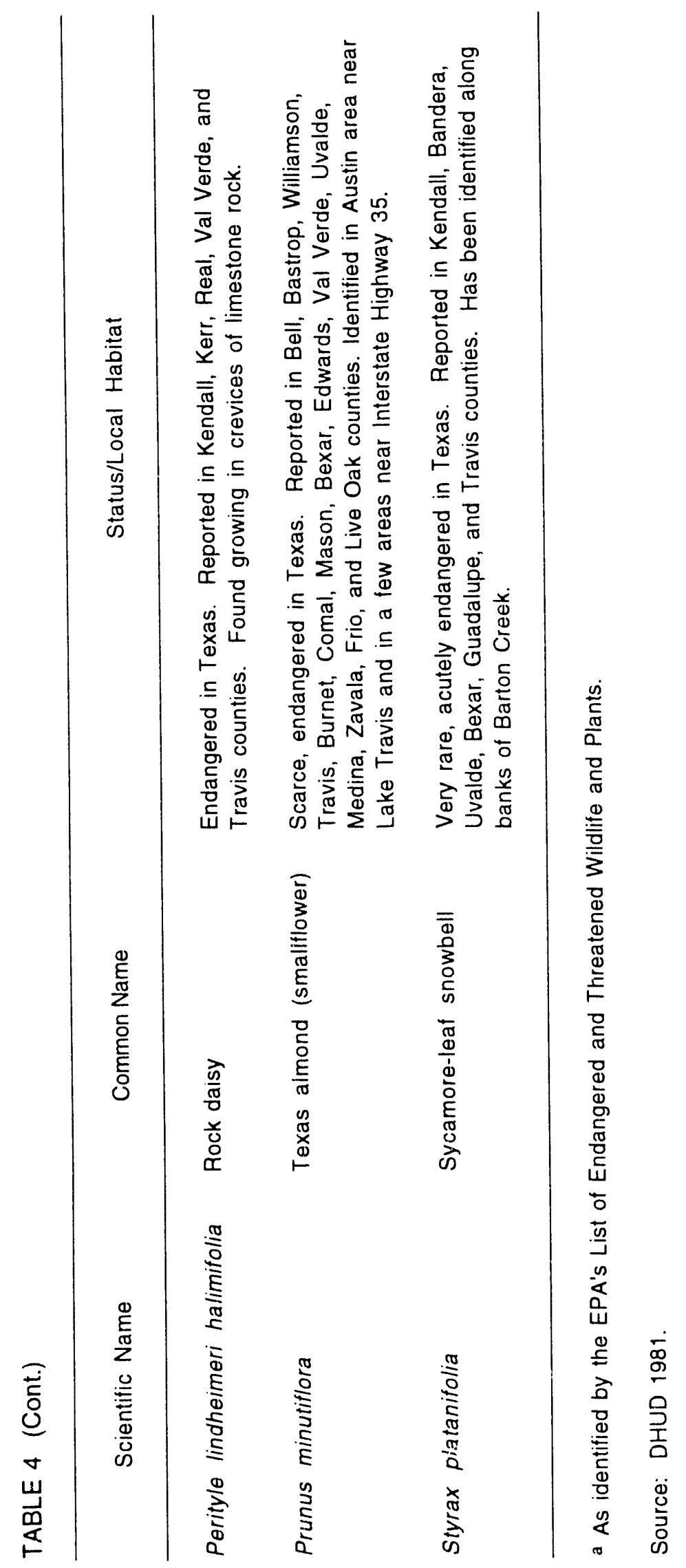




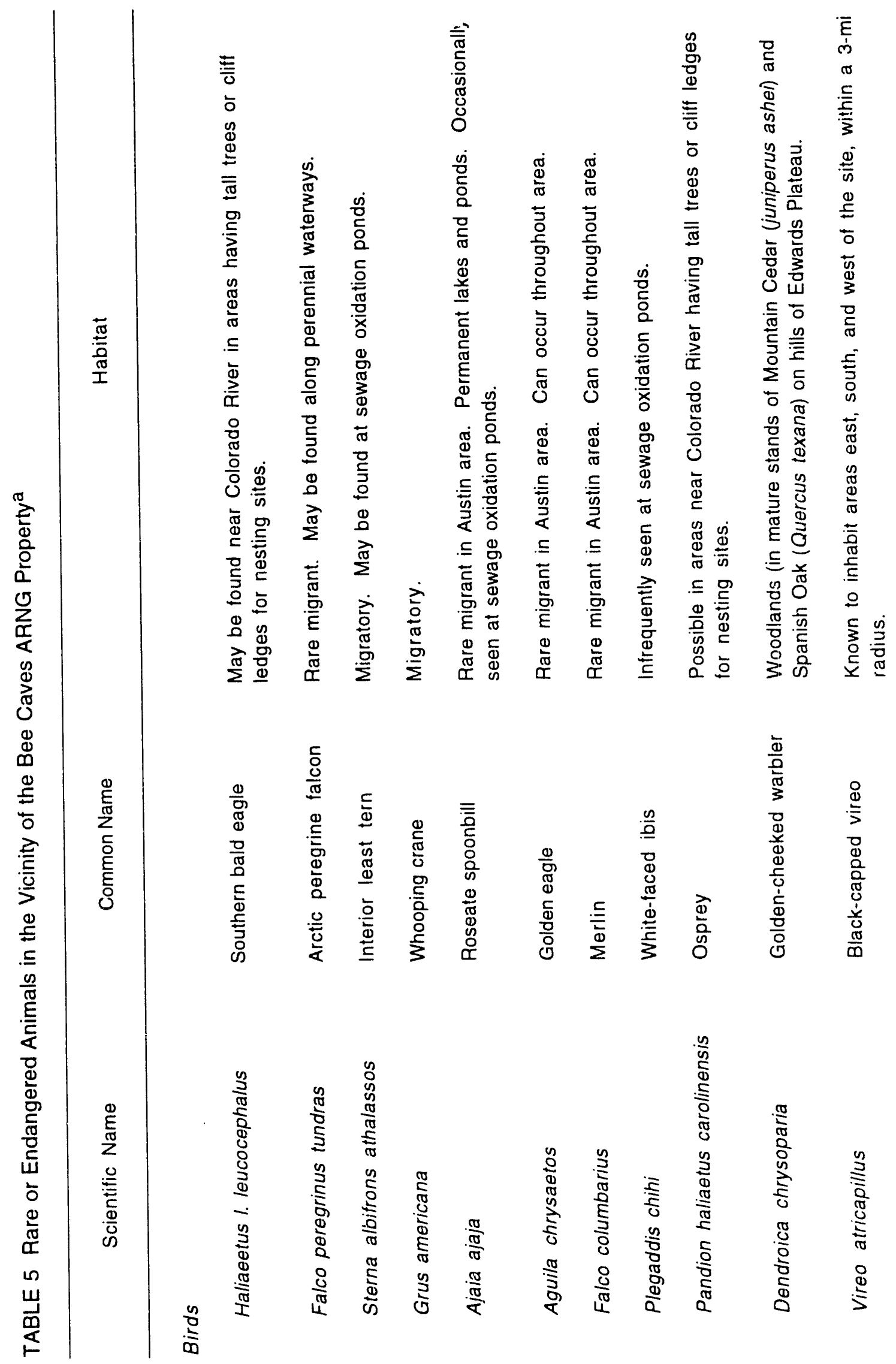




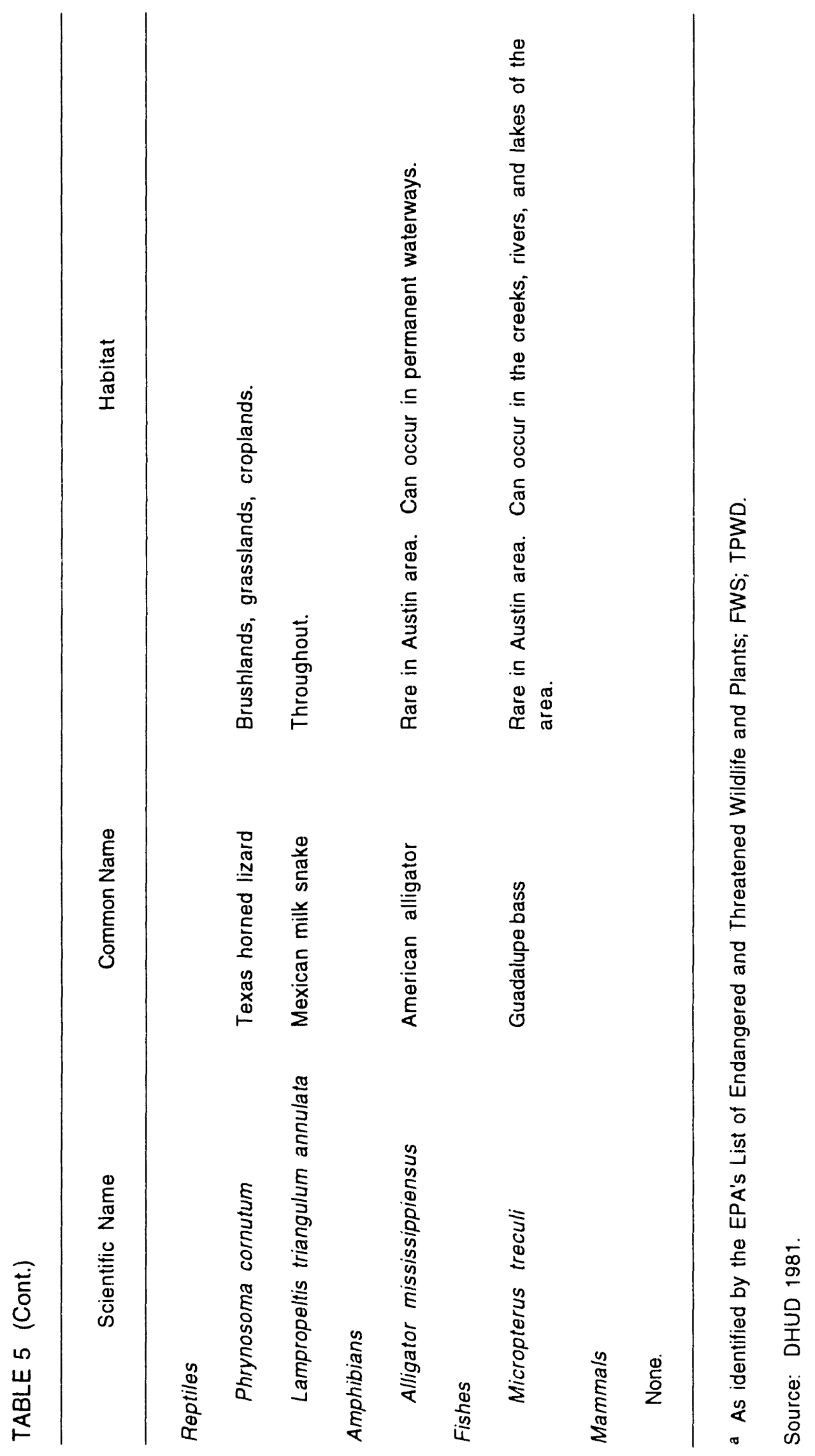




\section{Environmentally Significant Operations}

Current ARNG operations have little potential for risk to human health or to the environment. Training of the ARNG signal battalion personnel does not involve the use of significant quantities of hazardous materials and does not generate hazardous wastes. Solid waste disposal is through a low-bid private contractor, as needed. Of greater concern is the potential for hazardous waste to be present on the property as a result of the former Nike Missile Base operations or in the form of original construction materials. The PA team from Argonne identified four ESOs at the Bee Caves ARNG property: (1) underground fuel storage; (2) hazardous materials storage/use: (3) disposal of hazardous waste in dry wells; and (4) release of untreated waste water. Each ESO is described here. Figure 12 shows the general layout of the former Nike IFC facility and the locations of ESOs.

\subsection{Underground Fuel Storage}

Radar operations at the former Nike IFC facility required considerable electricity. An emergency power generator located in the Generator and Frequency Changer (GFC) Building (Figure 12) was served by a 6,000-gal UST containing diesel fuel that was constructed and installed in approximately 1958 (USTP 1986). The generating equipment inside the GFC Building was removed from the site when the Nike facility was deactivated, but the UST was left in place. During the years of Nike operations, generators were carefully maintained and routinely tested to ensure facility readiness. Throughput of diesel fuel at the former IFC area was considerable, requiring frequent refilling of the UST. Fuel storage in the UST is considered a potential ESO because fuel was likely to have spilled during the transfer and pumping operations. Additionally, the USTs may have leaked while the site operated, and fuel left in the tank after deactivation may have leaked as the UST deteriorated.

\subsection{Hazardous Materials Storage and Use}

The ARNG training activities do not require the use and storage of significant quantities of hazardous or flammable materials, although minor quantities are present primarily for house- and groundskeeping activities. A greater volume of hazardous materials was required as part of the former Nike IFC operations. Building 27 (the POL Storage Building) has been the primary storage location for hazardous materials since it was constructed in approximately 1960 . 


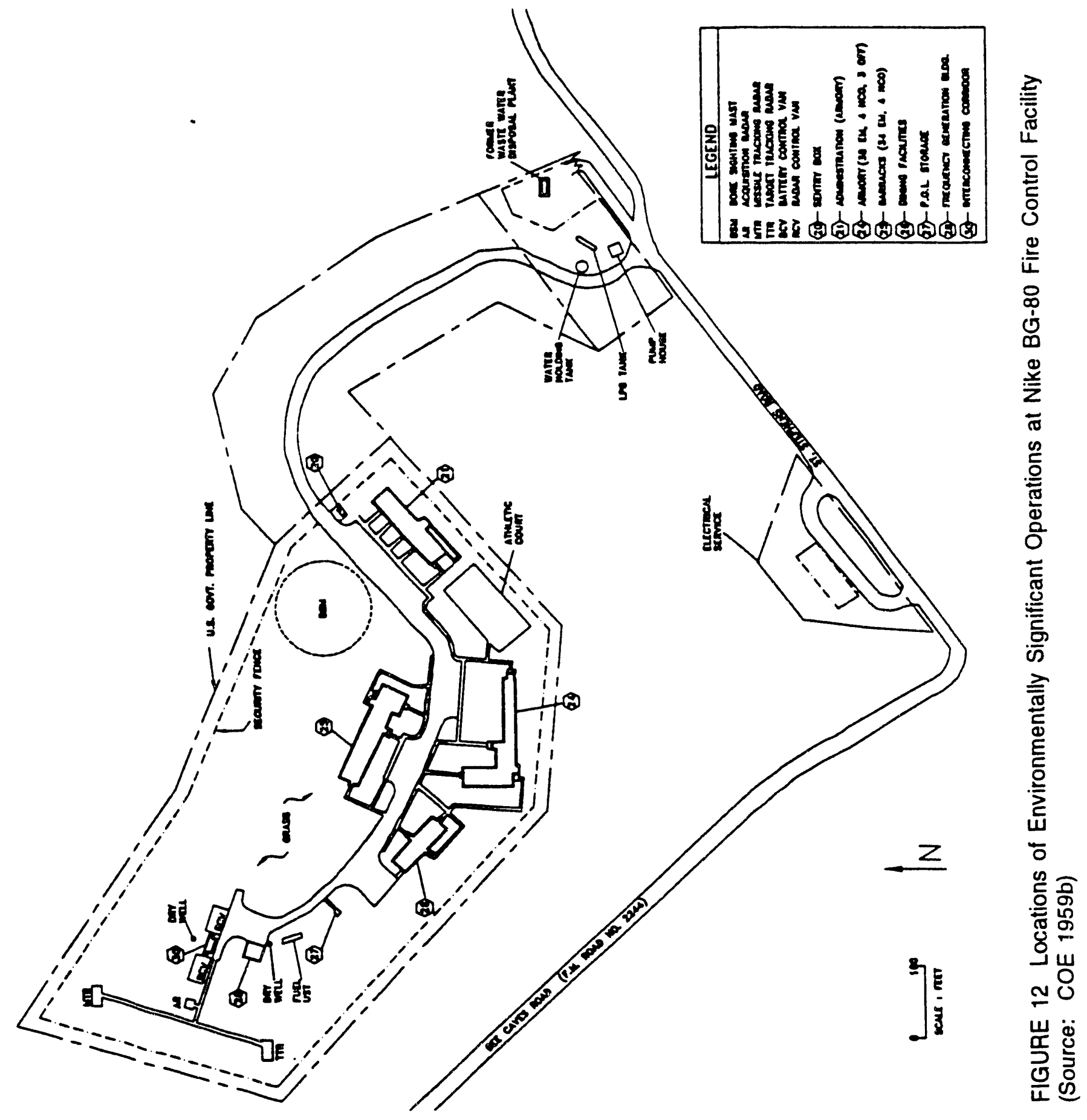


Building 20 (the former Nike IFC guardhouse) is used by the ARNG as a storage location for minor quantities of gasoline and paint-related products. The locations of Buildings 27 and 20 are shown in Figure 12. The following sections describe the hazardous materials that have been used at the facility as part of current or former operations or that are present on-site as construction materials.

\subsubsection{Use of Hazardous Materials in ARNG Operations}

The ARNG personnel use minor quantities of petroleum products to maintain, when necessary, the proper levels of motor oil and related fluids in the vehicles assigned to the unit. Regular vehicle maintenance and service are performed off-site. Minor quantities of gasoline and paint-related products are present for house- and groundskeeping. Ammunition is secured in the armory vault. Weapons cleaning performed twice per year requires the use of solvent. Pesticides and herbicides have only limited use at the ARNG facility. Table 6 contains an inventory of hazardous materials regularly used as part of ARNG operations at the Bee Caves facility (Hoffmann 1991).

\subsubsection{Use of Hazardous Materials in Nike IFC Operations}

The primary mission of the Nike IFC facility was radar tracking and missile guidance. Radar did not require extensive chemical use. Maintenance of radar was mostly electrical, using relatively small amounts of solvent for cleaning. The High-Power Acquisition Radar (HIPAR) system used a coolant pumping system consisting of an ethylene glycol circulating system and pump. The ethylene glycol was replaced annually. The pump was oil lubricated. Paint was the most significant chemical used on the radar systems. Common paints of the Nike period had lead (20 to $30 \%$ ) as a pigment.

Pesticides and herbicides had limited use at former Nike facilities. Pesticides were applied in limited amounts as warranted. Herbicides were used to maintain vegetation-free areas around site perimeters, primarily for fire control. As part of former Nike IFC operations, waste oil and hydraulic fluids were sometimes used to control vegetation along cable runs connecting a Nike IFC area with the MLA (LETC 1986). 
TABLE 6 Bee Caves Armory Hazardous Chemical Inventorya

\begin{tabular}{|c|c|c|c|}
\hline Chemical & Use & $\begin{array}{l}\text { Consumption } \\
\text { Rate }\end{array}$ & $\begin{array}{l}\text { Quantity } \\
\text { Stored }\end{array}$ \\
\hline \multicolumn{4}{|l|}{ Petroleum products } \\
\hline Motor oil & Maintain engine oil level & $2 \mathrm{qt} / \mathrm{mo}$ & $2 \mathrm{qt}$ \\
\hline Dexron II & Vehicle transmission fluid & $2 \mathrm{qt} / \mathrm{mo}$ & $2 \mathrm{qt}$ \\
\hline Siliconiz & Vehicle brake fluid & $1 \mathrm{qt} / \mathrm{mo}$ & $5 \mathrm{gal}$ \\
\hline Ethylene glycol & Engine antifreeze/coolant & $5 \mathrm{gal} / \mathrm{yr}$ & $5 \mathrm{gal}$ \\
\hline \multicolumn{4}{|l|}{ Solvents } \\
\hline Varsol & Weapons cleaning & $5 \mathrm{gal} / \mathrm{yr}$ & $5 \mathrm{gal}$ \\
\hline \multicolumn{4}{|l|}{ Flammable products } \\
\hline Gasoline & Groundskeeping equipment & - & $10 \mathrm{gal}$ \\
\hline Paint related ${ }^{b}$ & Minor paint touch-up & - & Approx. $20 \mathrm{gal}$ \\
\hline \multicolumn{4}{|l|}{ Ammunition } \\
\hline 22 Cal LR & Range qualification & $<500 \mathrm{rounds} / \mathrm{yr}$ & 4,200 \\
\hline $\begin{array}{l}\text { As reported in B } \\
\text { June 26, 1991, } \\
\text { Plan. }\end{array}$ & $\begin{array}{l}\text { aves Hazardous Materials In } \\
\text { TX ARNG 91-92 Waste Ma }\end{array}$ & $\begin{array}{l}\text { entory Checklist pre } \\
\text { nagement Pollution }\end{array}$ & $\begin{array}{l}\text { pared } \\
\text { Prevention }\end{array}$ \\
\hline
\end{tabular}

Fire control electronics used certain electronic tubes that contained low-level radiation sources in minute amounts. Regulation of these materials in the early years of the Nike program was less strict, and tubes may have been disposed with solid waste or "tossed on the ground" (LETC 1986). In the later years of the Nike program, these materials were more strictly controlled. A probable maximum of six of these tubes per year may have been discarded indiscriminately, and the risk to human health or the environment is considered negligible.

The quantity of hazardous materials stored and used at the Nike BG-80 IFC facility is unknown. However, as part of an investigation by the U.S. Army Corps of Engineers of former Nike missile sites for potential toxic and hazardous waste contamination, a general materials inventory of the Nike sites was formulated. Table 7 contains an inventory of hazardous materials likely used at the former BG-80 facility (LETC 1986). 
TABLE 7 Nike Integrated Fire Control Facility Hazardous Chemical Inventorya

\begin{tabular}{llr}
\hline \multicolumn{1}{c}{ Material } & \multicolumn{1}{c}{ Use } & $\begin{array}{c}\text { Annual Quantity } \\
\text { Used }\end{array}$ \\
\hline Asbestos & Insulation/fire proofing & $500 \mathrm{lb}$ (total) \\
Diesel fuel & Fuel for generators & $10,000 \mathrm{gal}$ \\
Electrical insulating oil & Electronics lubricant & $20 \mathrm{gal}$ \\
Ethylene glycol & HIPAR coolant & $25 \mathrm{gal}$ \\
Herbicides & Vegetation control & $20 \mathrm{lb}$ \\
Low-level radiation sources & Electrical tubes & $<1 \mathrm{lb}$ \\
Mineral spirits & Solvent/paint thinner & $500 \mathrm{gal}$ \\
Paints & Radar equipment, buildings & $300 \mathrm{gal}$ \\
$\quad$ (hydrocarbons and pigment) & Electric insulator & $100 \mathrm{gal} \mathrm{(total)}$ \\
Polychlorinated biphenyls & Paint & $100 \mathrm{lb}$ \\
Zinc chromate & & \\
\hline
\end{tabular}

a Materials typically used at a Nike IFC Facility.

b Other solvents may also have been used.

Source: LETC 1986.

\subsubsection{Hazardous Construction Materials}

Two hazardous materials were typically used as construction materials when the facility was developed as a Nike IFC area: polychlorinated biphenyls (PCBs) and asbestos (LETC 1986).

\subsubsection{Polychlorinated Biphenyl Compounds}

The PCBs in use at Nike sites were a component of dielectric fluid in transformers. When deactivation occurred, transformers remained on-site. Eventual deterioration of the sealed units may result in unit rupture with the subsequent release of small quantities of this carcinogen. The PCBs are relatively immobile in soils, and contamination, if release occurred, would be limited to the area in the immediate vicinity of the leaking transformer. Minor PCB contamination of surface soils has occurred at the facility as a result of a leaking transformer (ECAS 1992). See Section 4.3.2 for further discussion. 


\subsubsection{Asbestos}

Asbestos was in widespread use at Nike sites for building/equipment insulation purposes and as a component of some construction materials, including floor and ceiling tiles and wall siding. Asbestos is likely to have remained in place during and after Nike operation and would therefore be present on-site in its original form in buildings and on piping and ductwork, constituting a potential ESO. An asbestos survey performed in early 1993 confirmed the presence of asbestos in some building materials (Geo-Marine 1993). (Asbestos is not listed as a hazardous waste under CERCLA.) See Section 4.4 for further discussion.

\subsection{Disposal of Hazardous Waste in Dry Wells}

The locations of two dry wells are identified in the site plan of the former BG-80 IFC facility (COE 1959b). One well is located north of Building 30), formerly the Interconnecting Corridor (IC) between the Battery Control Van and the Radar Control Van, both of which were removed when the Nike facility was deactivated. The second well is located southeast of Building 28, the former GFC Building. Both the IC Building and the GFC Building are now used by the ARNG for storage of nonhazardous materials. The existence, locations, and use of the two dry wells could not be verified during the site survey, either by inspection of the site or through interviews with long-term ARNG personnel.

During the period of the Nike operations, dry wells were sometimes installed for the disposal of waste fluids such as oils, solvents, acids, and paints. These fluids were not strictly regulated at that time, and disposal in dry wells was an accepted disposal practice. A dry well is typically a narrow (2-3 ft in diameter), shallow (5-15 ft in depth) shaft, with concrete sidewalls and gravel/soil base.

\subsection{Release of Untreated or Hazardous Waste Water}

An abandoned sewage treatment plant, installed before 196(), is located at the entrance to the ARNG Site. The 15,()()()-gal-capacity system, designed to accommodate a 15()-person military unit and serve some 14 latrines, consisted of a chlorine treatment tank and clarifier tank with $1,662 \mathrm{ft}$ of line through the ARNG site (Bullock 1972). Treatment consisted of natural bacterial action breaking down the solids and disposal of liquids via evaporation (Day 1986). A system 
overflow discharge was located in the ravine southeast of the plant, where private homes have since been constructed.

In the years following transfer of the Bee Caves property to the ARNG, the integrity of the sewage treatment system became questionable. The system did not undergo regular maintenance, according to site personnel, including the periodic addition of chemicals required for proper operation. Although contents of the facility holding tank did not appear to increase appreciably and no discharge from the tank was observed, the lack of proper operation and maintenance could have allowed untreated sewage to drain into a creek off the facility property (Peters 1986). Because of the age of the system, the breaks in the underground sewer line could have occurred over time, thus allowing the underground discharge of untreated sewage before it reached the treatment plant. After an inspection of the former facility sanitary treatment system in July 1986, the facility was reported to be inoperative (Day 1986).

A new sewage treatment system has since been constructed and the former system abandoned. At that time, the discharge pipe was permanently sealed, and the treatment unit tanks were filled with sandy loam and seeded (Whisenhunt 1990; Dennis 1993).

During the years of Nike IFC operations, restrictions regarding the type of materials that could safely be disposed into a waste water treatment system were limited. In the absence of other convenient disposal options such as the two dry wells depicted in the 1959 site plan of the former Nike IFC facility, a waste water treatment system offered a convenient disposal option for some hazardous fluids, including solvents, herbicides, and neutralized battery acid. The presence of the dry wells as waste fluid disposal locations would likely preclude use of the waste water treatment system for this purpose. 


\section{i Known and Suspected Releases}

\subsection{Releases to Grcundwater}

The ESOs discussed here have the potential to release hazardous chemicals to groundwater in the vicinity of the Bee Caves Armory.

\subsubsection{Underground Fuel Storage}

The 6,000-gal diesel fuel UST adjacent to Building 28 was not used after ARNG operations began. Because of its age (approximately 30 years), the UST was considered to have a high probability of tank deterioration and subsequent leakage. Pressure testing of the UST in the spring of 1988 revealed that the fuel dispensing lines leading from the UST to the former generating equiprent inside the building had been sut to prevent discharge of the fuel. As the UST pressure test was initiated, an estimated 5-10 gal of diesel fuel were released inside the former GFC Building, used by the ARNG as a warehouse. The pressure test was terminated, and the released fuel was removed and discarded (Dennis 1993). The UST was excavated and removed in 1991. Topsoil at the ARNG property is thin and gravelly, so the UST was located in a limestone hed that minimized tank deterioration. Inspection of the UST and excavated soil/rock by site personnel indicated the tank to be in good condition with no evidence of significant subsurface contamination (Dennis 1993).

\subsubsection{Disposal of Hazardous Waste in Dry Wells}

The Bee Caves Nike IFC facility site plan dated June 1959 identifies the location of two dry wells, one north of the former IC Building and another near the southeast corner of the furmer GFC Building (COE 1959b). The existence and location of the two dry wells could not be confirmed during the site survey. W/hether disposal of hazardous wastes into either or both of these dry wells occurred is unknown. If it did, the dry wells constitute a migration pathway to groundwater in the vicinity.

Table 7 provides an inventory of hazardous materials typic aly present at the Nike facilities. The total vclume of hazardous chemials used at the site was not arge, and most materials such as diesel fuel, paints, solventsithinners, and herbicides would be largely consumed so that only a 
fraction would be disposed as waste. Other materials, such as asbestos and PCBs, were left in place when the former Nike IFC facility was deactivated. At a 5\% disposal rate, the volume of hazardous fluids, principally paint and solvents, potentially discarded into the dry wells each year can be estimated at less than 50 gal.

\subsubsection{Release of Untreated Waste Water}

In the years following transfer of the Bee Caves property to the ARNG, the integrity of the sewage treatment system became questionable. Contents of the facility holding tank did not appear to increase appreciably, and no discharge from the tank was observed. Because of the age of the system, the possibility was considered that breaks in the underground sewer line may have occurred over time, thus allowing the underground discharge of untreated sewage before it reached the treatment plant. An inspection of the former facility sanitary treatment system in July 1986 showed that the facility was inoperative (Day 1986). A new sewage treatment system has since been constructed and the former system abandoned.

During the years of use by the ARNG, the sewage treatment plant was significantly underutilized. ARNG activities consisted prima ly of training one weekend per month. If subsurface releases of untreated waste water occurred in past years, the volume released was low. During this period, no noticeable odors or incidents of effluent entering the waterway were reported (Day 1986).

\subsection{Releases to Surface Water}

No permanent bodies of surface water are present on-site. As discussed in Section 2.5.3.3, the ARNG property is located at the summit of a hill so that surface drainage is away from the property in all directions. Site elevation is shown in Figure 2. The Colorado River is located approximately $1 \mathrm{mi}$ north of the property, and Barton Creek is located approximately $1 \mathrm{mi}$ south of the property. The volume of hazardous materials historically used at the property as part of the former Nike operations, as well as ine current ARNG operations, was low. Because of the distance to the nearby surface waters and the permeability of the surface soils, it is highly unlikely that hazardous materials released to the surface soils at the property would have been carried via surface drainage to either surface water body. 


\subsection{Releases to Soil}

The ESOs discussed here have the potential to release hazardous chemicals to the soil in the vicinity of the Bee Caves Armory.

\subsubsection{Underground Fuel Storage}

Emergency power generators were routinely tested as part of normal Nike IFC operations, consuming large quantities of diesel fuel. An investigation of former Nike facilities for potential toxic and hazardous waste contamination by the U.S. Army Corps of Engineers noted that leakage and spillage of fuel during tank refilling operations was common (LETC 1986). No evidence of surface staining or stressed vegetation was evident at the former IFC UST location, however.

\subsubsection{Hazardous Materials Storage and Use}

Building 27 has been used to store hazardous materials (primarily petroleum products) during the former Nike IFC operations as well as during the current ARNG operations. Building 20 is currently being used by the ARNG to store minimal supplies of gasoline and paintrelated products; it was used as a guardhouse during the former Nike IFC operations. Both buildings have concrete foundations and sidewalls. Storage of hazardous materials has been of a limited volume over the years of operation. Inadvertent spills that may have occurred within the storage buildings would have been cleaned so that migration of contaminants outside the storage areas would have been minimized. Of greater risk to the environment and to human health are spills or releases of hazardous materials that have occurred beyond the Building 27 and Building 20 storage areas.

\subsubsection{Pesticides, Herbicides, and Waste Oil}

Pesticides and herbicides have limited current and historical use at the Bee Caves property. Application is sporadic and of low volume. As part of the former Nike IFC operations, waste oil and hydraulic fluids were routinely used to control vegetation along underground cable runs connecting the IFC area with the MLA. The volume of waste oil products generated as part of Nike IFC operations was low, limiting the volume available for this purpose. 


\subsubsection{Polychlorinated Biphenyl Compounds}

Formerly, PCBs were used as a component of dielectric fluid in transformers. Deterioration of a sealed transformer located on-site resulted in rupture of the unit and the subsequent release of a small quantity of this carcinogen in approximately 1990. Contamination was limited to the area in the immediate vicinity of the leaking transformer. Contaminated surface soils were removed by the local electrical utility when the leaking transformer was observed and reported (ECAS 1992).

\subsubsection{Release of Untreated Waste Water}

The former sewage treatment system had an overflow discharge directed to the ravine adjacent to the Bee Caves property. During the approximately 30 years since installation of the treatment system, private homes have been constructed in the ravine. The discharge point was periodically inspected during the years of ARNG operation, and no discharge from the system overflow point was observed. Because the system was underutilized, the potential for overflow was greatly reduced.

When the new sewage treatment system was completed and the former system abandoned, the discharge pipe was permanently sealed, and the treatment unit tanks were filled with sandy loam and seeded (Whisenhunt 1990; Dennis 1993).

\subsection{Releases to Air}

Routine operations performed as part of current ARNG activities or during the former Nike IFC activities did not result in the release of significant quantities of hazardous materials to the air. Fugitive dust and emissions resulting from the limited use of vehicles during current ARNG training exercises are discounted as an ESO.

A survey performed in early 1993 for the U.S. Army Corps of Engineers confirmed the presence of asbestos in certain building materials, including floor tiles and mastic, pipe lagging, transite boards, boiler covers, stack boot tar, and sheetrock duct work covers (Geo-Marine 1993). A total of 83 bulk samples of building materials were collected from the nine buildings inspected (the eight buildings located within the armory and training area at the crest of the hill and the water 
pump station located down the hill). Forty of the samples collected were identified as asbestos-containing materials (ACMs). Table 8 presents a summary of the samples of building construction materials collected that contained asbestos. Friable ACMs can be hazardous to building occupants because of the potential for release of asbestos fiber to the atmosphere. Recommendations for abatement of the friable and nonfriable ACMs were made in the survey report.

\subsection{Other Releases}

\subsubsection{Fire and Explosion}

Limited amounts of flammable materials are stored in the well-secured Flammable Storage Building (Building 20). An aboveground 3,500-gal LPG storage tank is, likewise, properly maintained and located within a fenced area. The threat of fire and explosion or direct contact by unauthorized persons is, therefore, minimized.

\subsubsection{Radiation}

Electronic tubes that contain low-level radiation sources in minute amounts were often disposed of indiscriminately in earlier portions of Nike site operations (LETC 1986). Tubes may have been disposed with solid waste or even "tossed on the ground." In later portions of the Nike program, these tubes were more strictly controlled. A probable maximum of six of these tubes per year were discarded in this manner, according to site interviews performed as part of the Corps of Engineer's toxic and hazardous waste investigation of former Nike sites (LETC 1986). Any tubes that may have been discarded on-site have almost certainly been destroyed by groundskeeping activities. The residual hazard of this material is negligible. 


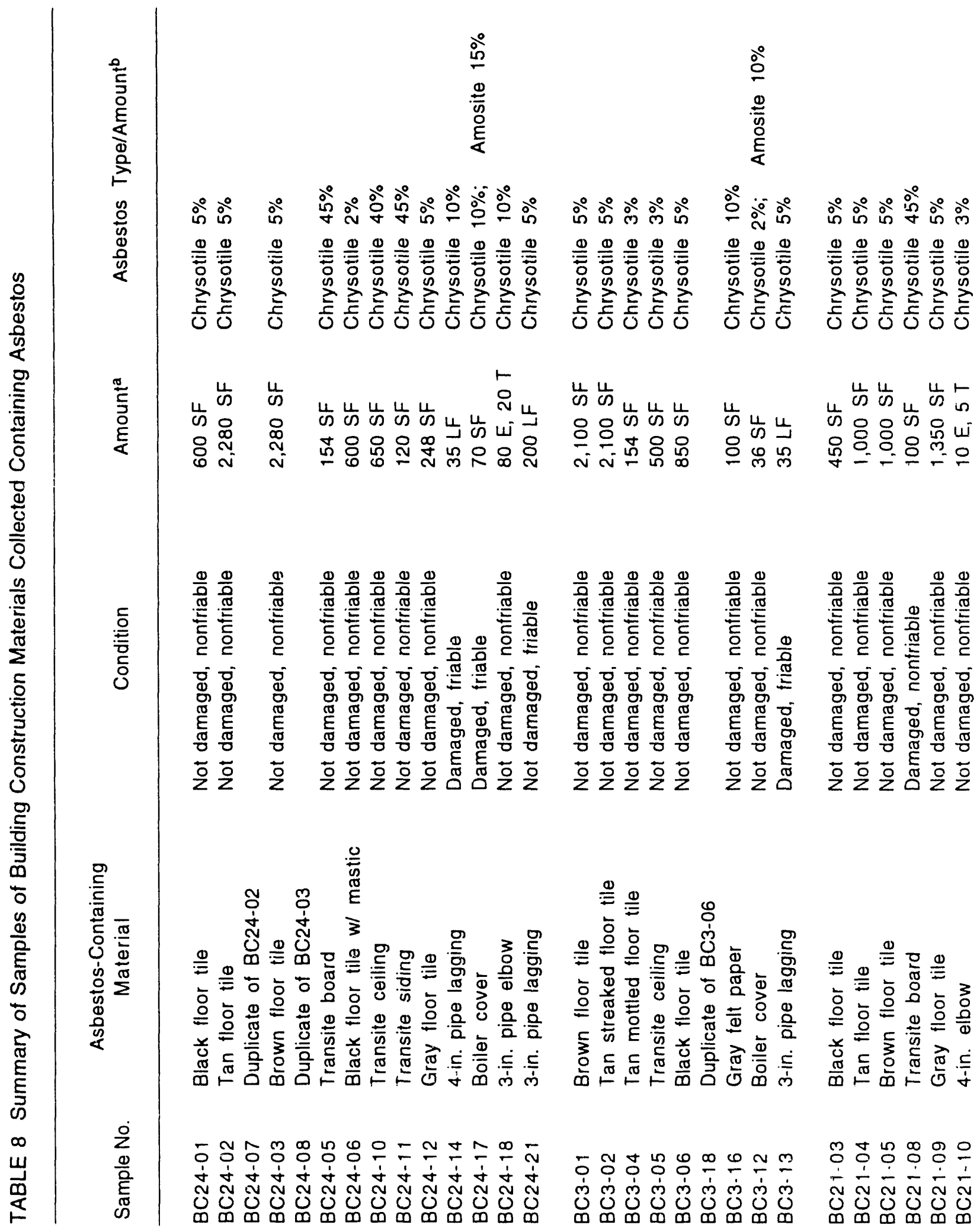




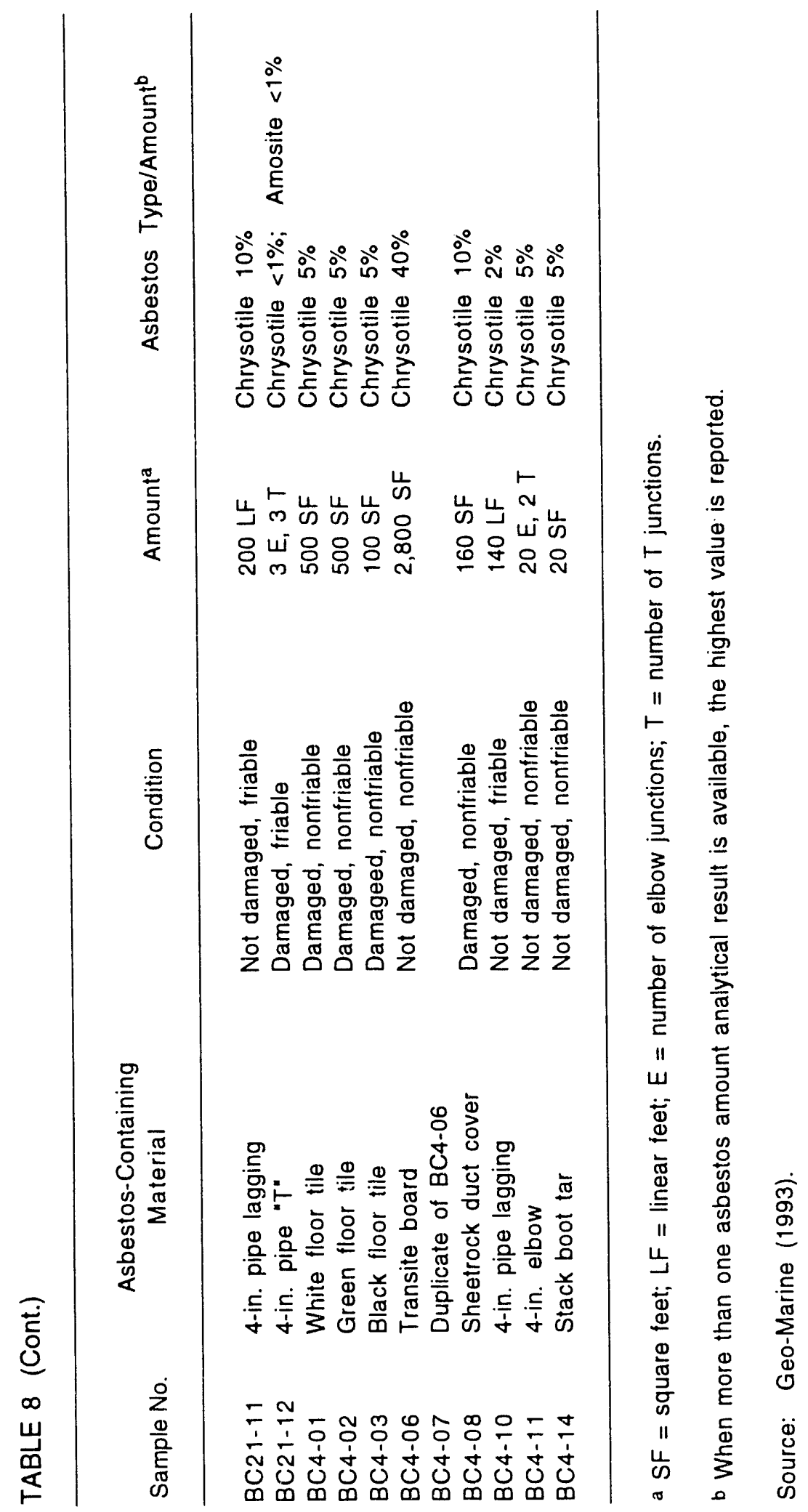




\section{Human and Environmental Receptors}

\subsection{Groundwater}

Groundwater from the Trinity and Edwards aquifers is used in the region as a source for municipal and domestic water, as well as irrigation and livestock needs. Underlying the ARNG property are the middle and lower Trinity aquifers. To the east of the ARNG property, the Edwards aquifer overlies the Trinity aquifer. The volume of hazardous waste present at the site in the form of surface or subsurface contamination is minimal because of the relatively low volume of hazardous materials used at the site during its years of operation. However, since infiltration of rainfall and surface water is the primary recharge mechanism for groundwater in the region, the potential for groundwater contamination must be considered.

Wells in the vicinity of the ARNG property that are drilled into the lower Trinity aquifer (typically the Hosston member) are not considered to be at risk because the impermeable Hammett Shale member of the Travis Peak Formation acts as a hydrologic barrier between the middle and lower Trinity aquifers. Nearby wells drilled into the middle Trinity aquifer (typically the lower Glen Rose Formation) are at minimal potential risk because of rainfall infiltration. The depth to the aquifer and the distance from the site to nearby wells combine to reduce the risk to well users.

The Edwards aquifer is largely separated from the ARNG property by the Balcones Fault Zone. Recharge to the Edwards aquifer is predominantly by several surface water flows located south and southeast of the ARNG property. No connecting surface water flow to any of these streams exists. The distance between the Bee Caves facility and any of the recharge streams would minimize the risk to the Edwards aquifer from any contamination present on the ARNG property.

\subsection{Surface Water}

No on-site permanent streams or surface water bodies connect to the nearby Barton Creek to the south or the Colorado River to the north, the primary source of drinking water for the Austin area. The quantity of hazardous materials historically used at the property is low, and the porous and gravelly soils of the site cause nearly all precipitation to be rapidly absorbed. No impact to surface water resources in the area is evident. 


\subsection{Soil}

Releases to surface soils as a result of ARNG activities (i.e., groundskeeping activities or the previously used vehicle wash rack) are not considered a significant environmental concern. Releases to surface soils during the former Nike IFC operations (i.e., spills that likely occurred during the frequent refilling of the 6,000-gal UST or application of herbicides or waste oil to deter vegetation growth) were not of a significant volume. Neither staining of surface soils nor distressed vegetation associated with past substantial surface releases is apparent. Surface drainage during the intervening 30 years has diluted the concentrations of the hazardous materials so that they are unlikely to pose a risk to site personnel or nearby civilians.

\subsection{Air}

Limited fugitive dust and vehicle emissions result from the use of military vehicles when the two units assigned to the facility assemble for training exercises. However, there are currently no permit requirements. Exposure via air of the off-site population to ARNG-generated contamination is unlikely.

Asbestos present in original building construction materials poses a risk to building occupants. The risk to persons off-site via air transport is minimal.

\subsection{Other Receptors}

The 12.55-acre ARNG property is enclosed by a fence and gate, preventing entrance by the surrounding civilian population. Because of the low volumes of hazardous materials that have historically been stored and used at the property, the potential for transport of significant quantities of these materials off-site is small. The transport of measurable quantities of hazardous materials via surface or subsurface pathways from the ARNG property to the Lake Austin and Town Lake reservoirs and public use areas and to the Wild Basin Wilderness Park is unlikely. 


\section{Preliminary Assessment Findings and Conclusions}

\subsection{Summary of Preliminary Assessment Findings}

The ARNG Bee Caves Armory is 12.55 acres located in the western portion of Travis County, Texas, west of the city limits of Austin. The property is bordered by a residential area known as the Rob Roy subdivision. Separating this area from Austin, Texas, are the two suburbs of West Lake Hills and Rollingwood. West of the site, the area remains largely undeveloped. The Colorado River is located approximately $1 \mathrm{mi}$ north of the property, and Barton Creek is located approximately $1 \mathrm{mi}$ south of the property. These surface waters are the major source of drinking water for the region. Groundwater in the Trinity Sands aquifer at a depth of 200-700 $\mathrm{ft}$ is also a source of drinking water, primarily for rural populations located upgradient of the ARNG property (DHUD 1981).

The Bee Caves ARNG property is licensed to the Texas National Guard as an armory and division data center. The facility is occupied by the 111 th Area Support Group and the 1104th Transportation Detachment. The two units, with a total authorized strength of 139 , assemble for training one weekend per month. ARNG training activities at the facility are limited, consisting primarily of classroom-type activities. Hazardous materiais are stored and used by site personnel only as part of general house- and groundskeeping activities. Wastes generated are not considered to be of a hazardous nature. Vehicles assigned to the unit receive service and maintenance at nearby Camp Swift.

The property was formerly used as part of the Nike-Hercules Missile Defense System. It was an IFC facility of the Bergstrom Defense area. The associated MLA was not part of this property. Four ESOs associated with the former Nike-Hercules IFC area operations were identified at the property: (1) underground fuel storage, (2) hazardous materials storage/use, (3) disposal of hazardous waste into two dry wells, and (4) release of untreated waste water.

\subsubsection{Underground Fuel Storage}

Pressure testing of the 6,000-gal UST located south of the former generator building was performed in 1987. Diesel fuel was determined to be present in the tank. Because of its age, corrosion and leakage of the tank were considered probable. The UST was removed in 1991. 
After excavation, the UST was reported to be in good condition. Inspection of the UST and excavated soil/rock indicated that release of significant quantities of hazardous materials did not occur.

\subsubsection{Hazardous Materials Storage and Use}

The primary mission of the Nike IFC area was radar tracking and missile guidance. Radar did not require extensive chemical use. Maintenance of radar was mostly electrical, using relatively small amounts of solvent for cleaning. The HIPAR used a coolant pumping system consisting of the coolant ethylene glycol and an oil-lubricated pump. Paint was the most significant chemical used on radar systems. The volume of hazardous materials required on-site as part of Nike missile fire control activities was low, and most of these materials were consumed.

Two materials now recognized as hazardous were used as construction materials when the facility was developed in approximately 1960 as a Nike IFC Area. PCBs were formerly used as a component of dielectric fluid in sealed electric transformers. Deterioration of one transformer resulted in the leakage of a small quantity of PCBs to surface soils. The defective transformer was taken out of service, and the contaminated surface soils were removed (Dennis 1993). A survey of site buildings performed in early 1993 under the direction of the U.S. Army Corps of Engineers confirmed the presence of asbestos in some building construction and insulation materials (Geo-Marine 1993).

\subsubsection{Disposal of Hazardous Waste into Two Dry Wells}

According to the 1959 site plan of the former Bee Caves IFC facility (COE 1959b), a dry well was installed north of Building 30 , formerly the interconnecting corridor between the battery control van and the radar control van, both of which were removed when the Nike facility was deactivated. A second dry well was apparently installed southeast of Building 28, the former generator building. The presence of the dry wells could not be confirmed during the site survey. No documentation is available regarding the construction of the two dry wells or their use, although dry wells offered convenient disposal locations for potentially hazardous materials such as oil, solvents, and acids. Relatively minor quantities of these materials were typically present at Nike IFC facilities. If the dry wells were present as indicated in the site plan and then were filled at the time of deactivation of the former Nike site, use of the dry wells for disposal of the limited quantities of hazardous waste fluids generated as part of the former Nike IFC operations is unlikely 
to have resulted in the release of hazardous constituents sufficient to pose a significant threat to the environment or to the surrounding population.

\subsubsection{Release of Untreated or Hazardous Waste Water from the Facility Water Treatment System}

The aging sewage treatment facility constructed when the property was developed as a Nike IFC facility has been abandoned. Contents of the system holding tank were removed for disposal, and the holding tanks were filled with sandy loam and seeded. The facility has been replaced by an upgraded treatment facility approved by the local health authorities.

\subsection{Recommendations for Further Action}

The primary objective of the PA is to identify and evaluate ESOs that would result in either (1) immediate action, (2) site investigation, or (3) no further PA/IRP action. The nature of the training activities at the Bee Caves Armory is such that no current ARNG operations are considered to have a significant adverse impact on the environment. Storage of flammable materials in the POL Storage Building is extremely limited, only of the type and amount required for groundskeeping activities. A higher volume of hazardous materials was present on the site when it was used as a Nike-Hercules missile fire control area. Most of these materials were consumed onsite as part of normal operations or were removed at the time of deactivation of the site as a Nike facility. The volume of hazardous materials that may have been released to the surface and subsurface soils of the property is unlikely to pose a significant threat to human health or to the environment. Because of the actions taken to mitigate potential contamination at the site, no further PA/IRP action is recommended for this property. To protect workers on the site, abatement of ACMs, as outlined in the February 1993 asbestos survey, is recomended. 


\section{References}

ATCHD, 1991, License to Operate an On-Site Sewerage Facility at Bee Caves Armory, Facility Permit No. 7372, Austin-Travis County Health Department, Austin, Texas (April 31 ).

Baker E.T., et al., 1986, Geohydrology of the Edwards Aquifer in the Austin Area. Texas, U.S. Geological Survey, Texas Water Development Board, Report 293 (March).

Bishop, T.S., 1965, Memo from General T.S. Bishop, Adjutant General of the State of Texas, to Colonel Schupp, U.S. Properties and Fiscal Office for the State of Texas, regarding the Texas Army National Guard's desire to secure the Bee Caves Nike Site in Austin, Texas, as an armory location (December 10).

Bradley, G.L., 1978. Letter from G.L. Bradley, Austin, Texas, to LTC L.J. Starr, Chief, Facility and Engineering Branch, Texas Army National Guard, requesting permission to erect a 750,000-gal water reservoir $75 \mathrm{ft}$ in height on Bee Caves ARNG property (May 1).

Brune, G., 1983, Occurrence, Availability, and Quality of Groundwater Resources in Travis County, Texas, Texas Department of Water Resources, Report No. 276 (June).

Bullock, 1972, Department of Defense Examination of U.S. Army Guard/Reserve Facilities. Report from Major Bullock, Pennsylvania Army National Guard, for Bee Cave National Guard Armory, Control No. TX 010(G) (June 28).

Cain, J.P., 1985, Letter from J.P. Cain, Chief, Real Estates Division, Texas Army National Guard, to J.J. Amis, President, Urban Associates, consenting to an easement onto Bee Caves ARNG property for placement of an 8-in. water line to adjacent residential properties, Consent to Easement No. DACA63-9-85-0541 (March 29).

COE, 1959a, BG-80 Control Area Grading and Drainage Plan, Bergstrom Air Force Base Defense Area, Texas, U.S. Army Corps of Engineers, Galveston District (June 16).

COE, 1959b, Site Plan of BG-80 Control Area, Bergstrom Air Force Base Defense Area, Texas, U.S. Army Corps of Engineers, Galveston District (June 16). 
Day, R.K., 1986, Memo from Colonel R.K. Day, Chief of Staff, Texas Army National Guard, to The Adjutant General of the State of Texas regarding a site inspection of the Bee Caves Armory sanitary sewer system (July 24 ).

Dennis, C.B., 1993, Unpublished site reconnaissance and interview notes for Preliminary Assessment of Bee Caves Armory, Austin, Texas (February).

DHUD, 1981, Areawide Environmental Impact Statement for the North Sector Growth Area Travis \& Williamson Counties, Texas, U.S. Department of Housing and Urban Development. San Antonio Area Office (June 15).

ECAS, 1992, Out-Briefing Summary of the ECAS Visit to Bee Caves Armory, Environmental Compliance Assessment System, National Guard Bureau, (March 4).

Ellison. J.P., 1990, Letter from S.P. Ellison, Senior Staff Engineer. Environmental Health Services Division, Austin-Travis County Health Department, Austin, Texas, to Cliff Hall, Director of Technical Programs, Adjutant General's Department. Texas Army National Guard, regarding review and approval for construction of an on-site sewer facility at Bee Caves Armory, Facility Permit No. 7372 (June 16).

ESE, 1984, Historical Overview of the Nike Missile System. Environmental Science and Engineering, Inc., Gainesville, Florida, prepared for the U.S. Army Toxic and Hazardous Materials Agency, Aberdeen Proving Ground, Maryland, Report No. DRXTH-AS-IA-83()I6 (December).

Flores, R., 1990, Test Well Drilling Investigation to Delineate the Downdip Limits of UsableQuality Ground Water in the Edwards Aquifer in the Austin Region. Texas, Texas Water Development Board, Report 325 (April).

Geo-Marine, 1993, Asbestos Survey of Bee Cave Armory, 408 St. Stephens Road, Austin, Texas, Geo-Marine, Inc., Plano, Texas. prepared for the U.S. Army Corps of Engineer: Contract No. DACA63-9()-D-()()61, Delivery Order No. ()i)44 (February). 
GSA. 1988. Survey Report for the Bee Cave National Guard Armory, Austin, Texas, General Services Administration. Federal Property Resources Service, Washington, D.C., GAS Inventory Control No. 210()-22323 (April 7).

Hoffmann, G.A.. 1991. Memo from SFC G.A. Hoffmann, 111 th Area Support Group, Bee Caves Armory, wo the Commander, Environmental Section, Texas Army National Guard, containing the Bee Caves Hazardous Materials Inventosy Checklist (June 27).

LETC. 1986. Investigation of Former Nike Missile Sites for Po.ential Toxic and Hazardous Waste Contamination, Volumes 1 and 2, Law Engineering Testing Company, LES-Government Services Division, Atlanta. Georgia. prepared for the U.S. Army Coif of Engineers, Huntsville Division, under Contract No. DACA87-85-C-0104 (March).

Lloyd, A.. 1977, Letter from A. Lloyd, Austin, Texas, to Major General T.S. Bishop, Texas Army National Guard, requesting a roadway easement and permis. - on to link residential properties to be developed adjacent to the Bee Caves ARNG property into that facility's sanitary sewer system (December 7).

NGB, 1987, Army National Guard Facility Inventory and Stationing Plan (FISP), U.S. Army National Guard, Aberdeen, Maryland (January).

NOAA, 1988, Climatological Data Annual Summary, Texas, 1988, National Oceanic and Atmospheric A dministration, National Climatic Data Center, Report ISSN 0364-6041, Asheville, North Carolina.

Patterson, J.L., 1963, Floods in Texas - Magnitude and Frequency of Peak Flows, U.S. Geological Survey, Texas Water Commission Bulletin 6311 (December).

Peters, R.C., 1986, Memo from LTC R.C. Peters, Headquarters, 111 th Support Group, Bee Caves Armory, to The Adjutant General of the State of Texas regarding the status of the sanitary sewage system at the Bee Caves Armory (July 1).

Peters, R.C., 1991, Army National Guard Environment ll Compliance Assessment Previsit Questionnaire (December 19). 
Rand McNally, 1992, Rand McNally 1992 Atlas, Rand McNally and Company, Chicago, Illinois.

Rochford, A.B., 1966, Memo from Colonel A.B. Rochford, National Guard Bureau, Chief, Army Installations Division, to The Adjutant General, State of Texas, Austin, Texas, regarding the acquisition of excess Nike-Hercules facilities for the state of Texas (May 31).

Senger, R.K., et al., 1984, Hydrogeology of the Edwards Aquifer, Austin Area, Central Texas, University of Texas at Austin, Bureau of Economic Geology, Report No. 141.

Slade, R.M., et al., 1986, Hydrology and Water Quality of the Edwards Aquifer Associated with Barton Springs in the Austin Area, Texas, U.S. Geological Survey, Water Resources Investigation Report No. 86-4036.

Starr, J., 1978a, Memo from LTC J. Starr, Chief, Facility and Engineering Branch to The Adjutant General of the State of Texas regarding a December 7, 1977, request by Mr. A. Lloyd for utilization of Bee Caves Armory facilities (May 18).

Starr, J. 1978b, Memo from LTC J. Starr, Chief, Facility and Engineering Branch, Texas Army National Guard, to The Adjutant General of the State of Texas regarding a May 1, 1978, request by Mr. G.L. Bradley for use of Bee Caves ARNG property.

Starr, J., 1985, Memo from Colonel L.J. Starr, Director of Facilities and Engineering, Texas Army National Guard, to The Adjutant General of the State of Texas regarding Amendment No. 1 to License DACW63-3-81-0502, Nike-Hercules Defense Site (May 28).

TWC, 1989, Groundwater Quality of Texas - An Overview of Natural and Man-Affected Conditions, Texas Water Commission, Groundwater Protection Unit, Report 89-01 (March).

TWC, 1993, Records of Wells Filed with the State of Texas through the Texas Water Well Drillers Board, Texas Water Commission.

TWDB, 1976, Groundwater Resources of Part of Central Texas with Emphasis on the Antlers and Travis Peak Formations, Texas Water Development Board, Texas Department of Water Resources, Report 195. 
TXARNG, 1980, Site Plan of Austin-Bee Caves, Texas Army National Guard, Camp Mabry, Office of Facilities and Engineering, Austin, Texas, (February 12).

USGS, 1988a, Topographic Map - Austin West Quadrangle - Travis County, Texas, U.S. Department of the Interior Geological Survey, No. 30097-C7-TF-024.

USGS, 1988b, Topographic Map - Austin East Quadrangle - Travis County, Texas, U.S. Department of the Interior Geological Survey, No. 30097-C6-TF-024.

USTP, 1986, "Notification for Underground Storage Tanks," Underground Storage Tank Program, Texas Water Commission, Austin, Texas, Texas ARNG UST Information (April 22).

Webster, R.K., 1967, Memo frot . Colonel R.K. Webster, Department Engineer, Texas Army National Guard, to The Adjutant General of the State of Texas, regarding the activation of the Bee Caves Nike site as a weekend training site for the Texas Army National Guard (May 10).

Whisenhunt, B.J., 1990, Letter from Colonel B.J. Whisenhunt, Direciur, Facilities and Engineering, Adjutant General's Department, Texas Army National Guard requesting bid for the construction of an on-site sewage treatment facility at the Bee Caves Armory based on an attached scope of work (August 1). 
Appendix:

Interview Information 
PA for Bee Caves Armory 
Appendix:

Interview Information

\section{Individuals and Agencies Interviewed}

Environmental Officer

Texas Army National Guard

Camp Mabry

Austin, Texas

Environmental Officer

Texas Army National Guard

Camp Mabry

Austin, Texas

Construction Inspector (retired)

Texas Army National Guard

Austin, Texas
Texas Water Commission

Well Drillers Board

Austin, Texas

U.S. Department of Agriculture

Soil Conservation Service

Austin, Texas

U.S. Geological Survey

Texas Water Development Board

Austin, Texas

\section{Argonne Investigators}

Clyde Dennis

(708) 252-5999

George Hildebrandt

(708) 252-4991

Candace Rose

(708) 252-3499 

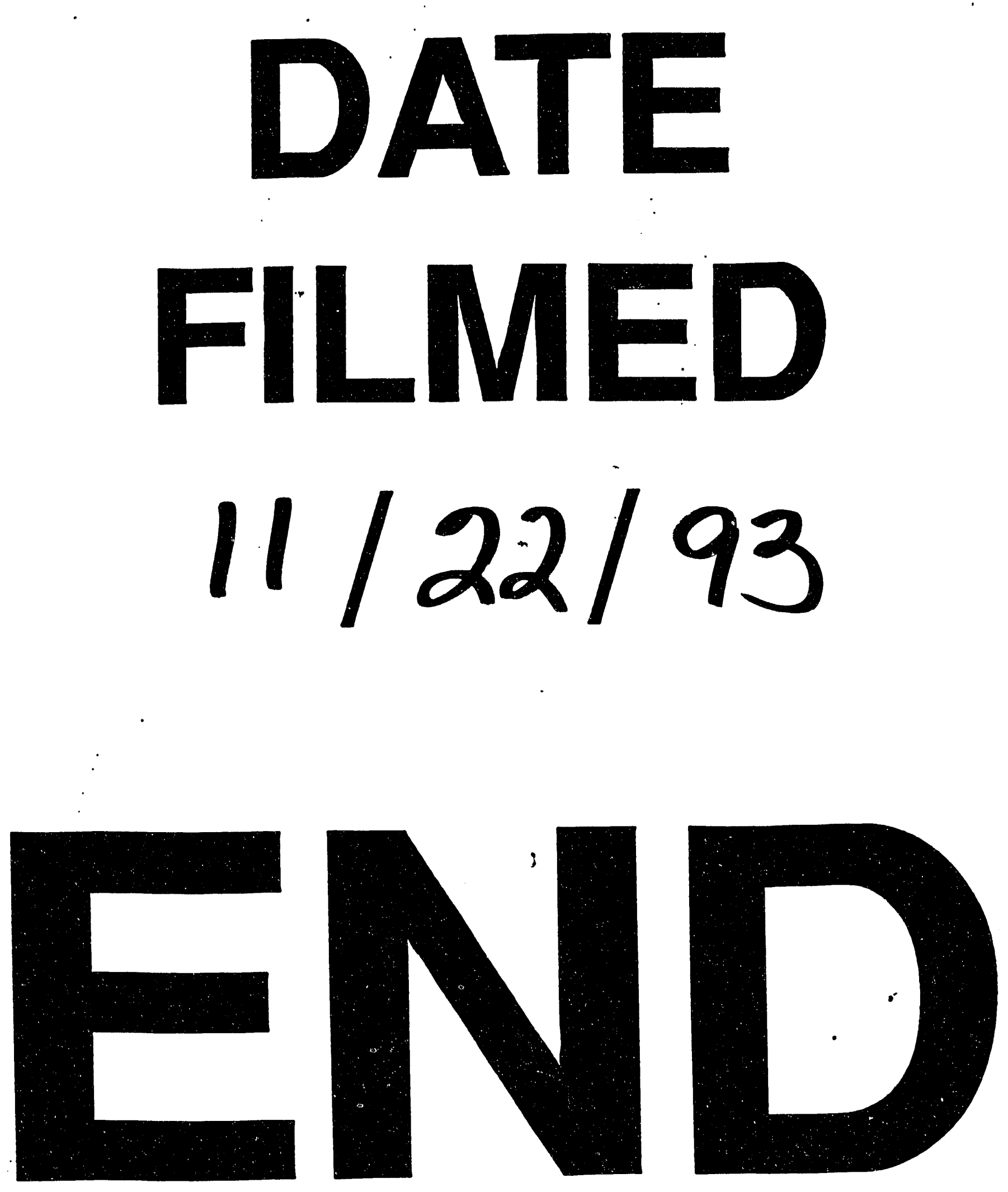
